\title{
Explaining Female and Male Entrepreneurship at the Country Level
}

\author{
Ingrid Verheul, André van Stel and Roy Thurik
}

\begin{tabular}{|l|l|}
\hline \multicolumn{2}{|l|}{ ERIM REPORT SERIES RESEARCH IN MANAGEMENT } \\
\hline ERIM Report Series reference number & ERS-2005-089-ORG \\
\hline Publication & December 2005 \\
\hline Number of pages & 51 \\
\hline Persistent paper URL & \\
\hline Email address corresponding author & verheul@few.eur.nl \\
\hline Address & Erasmus Research Institute of Management (ERIM) \\
& RSM Erasmus University / Erasmus School of Economics \\
& Erasmus Universiteit Rotterdam \\
& P.O.Box 1738 \\
& 3000 DR Rotterdam, The Netherlands \\
& Phone: $\quad+31104081182$ \\
& Fax: $\quad+31104089640$ \\
& Email: info@erim.eur.nl \\
& Internet: $\quad$ www.erim.eur.nl \\
\hline
\end{tabular}

Bibliographic data and classifications of all the ERIM reports are also available on the ERIM website: www.erim.eur.nl 


\section{ERASMUS RESEARCH INSTITUTE OF MANAGEMENT}

\section{REPORT SERIES}

\section{RESEARCH IN MANAGEMENT}

\begin{tabular}{|c|c|}
\hline \multicolumn{2}{|c|}{ ABSTRACT AND KEYWORDS } \\
\hline Abstract & $\begin{array}{l}\text { Using Global Entrepreneurship Monitor data for } 29 \text { countries this study investigates the } \\
\text { (differential) impact of several factors on female and male entrepreneurship at the country level. } \\
\text { These factors are derived from three streams of literature, including that on entrepreneurship in } \\
\text { general, on female labor force participation and on female entrepreneurship. The paper deals } \\
\text { with the methodological aspects of investigating (female) entrepreneurship by distinguishing } \\
\text { between two measures of female entrepreneurship: the number of female entrepreneurs and the } \\
\text { share of women in the total number of entrepreneurs. The first measure is used to investigate } \\
\text { whether variables have an impact on entrepreneurship in general (influencing both the number } \\
\text { of female and male entrepreneurs). The second measure is used to investigate whether factors } \\
\text { have a differential relative impact on female and male entrepreneurship, i.e., whether they } \\
\text { influence the diversity or gender composition of entrepreneurship. Findings indicate that - by } \\
\text { and large - female and male entrepreneurial activity rates are influenced by the same factors } \\
\text { and in the same direction. However, for some factors (e.g., unemployment, life satisfaction) we } \\
\text { find a differential impact on female and male entrepreneurship. The present study also shows } \\
\text { that the factors influencing the number of female entrepreneurs may be different from those } \\
\text { influencing the share of female entrepreneurs. In this light it is important that governments are } \\
\text { aware of what they want to accomplish (i.e., do they want to stimulate the number of female } \\
\text { entrepreneurs or the gender composition of entrepreneurship) to be able to select appropriate } \\
\text { policy measures. }\end{array}$ \\
\hline Free Keywords & Entrepreneurship, Gender, Determinants of Entrepreneurship \\
\hline Availability & $\begin{array}{l}\text { The ERIM Report Series is distributed through the following platforms: } \\
\text { Academic Repository at Erasmus University (DEAR), DEAR ERIM Series Portal } \\
\text { Social Science Research Network (SSRN), SSRN ERIM Series Webpage } \\
\text { Research Papers in Economics (REPEC), REPEC ERIM Series Webpage }\end{array}$ \\
\hline Classifications & $\begin{array}{l}\text { The electronic versions of the papers in the ERIM report Series contain bibliographic metadata } \\
\text { by the following classification systems: } \\
\text { Library of Congress Classification, (LCC) LCC Webpage } \\
\text { Journal of Economic Literature, (JEL), JEL Webpage } \\
\text { ACM Computing Classification System CCS Webpage } \\
\text { Inspec Classification scheme (ICS), ICS Webpage }\end{array}$ \\
\hline
\end{tabular}




\title{
Explaining female and male entrepreneurship at the country level ${ }^{*}$
}

\author{
Ingrid Verheul ${ }^{1,2}$, André van Stel ${ }^{1,2,3}$ and Roy Thurik ${ }^{1,2,3}$ \\ ${ }^{1}$ Centre for Advanced Small Business Economics (CASBEC), \\ Erasmus University Rotterdam, \\ P.O. Box 1738, 3000 DR Rotterdam, the Netherlands. \\ ${ }^{2}$ EIM Business and Policy Research, \\ P.O. Box 7001, 2701 AA Zoetermeer, the Netherlands \\ ${ }^{3}$ Max Planck Institute of Economics, \\ Kahlaïsche Straße 10, D-07745 Jena, Germany
}

* Corresponding author: Ingrid Verheul, Centre for Advanced Small Business Economics (CASBEC), H12-18, Erasmus University Rotterdam, P.O. Box 1738, 3000 DR Rotterdam, the Netherlands, tel. +31 10 4081422, fax.+31 10 4089141, e-mail: verheul@few.eur.nl

\begin{abstract}
Using Global Entrepreneurship Monitor data for 29 countries this study investigates the (differential) impact of several factors on female and male entrepreneurship at the country level. These factors are derived from three streams of literature, including that on entrepreneurship in general, on female labor force participation and on female entrepreneurship. The paper deals with the methodological aspects of investigating (female) entrepreneurship by distinguishing between two measures of female entrepreneurship: the number of female entrepreneurs and the share of women in the total number of entrepreneurs. The first measure is used to investigate whether variables have an impact on entrepreneurship in general (influencing both the number of female and male entrepreneurs). The second measure is used to investigate whether factors have a differential relative impact on female and male entrepreneurship, i.e., whether they influence the diversity or gender composition of entrepreneurship. Findings indicate that - by and large - female and male entrepreneurial activity rates are influenced by the same factors and in the same direction. However, for some factors (e.g., unemployment, life satisfaction) we find a differential impact on female and male entrepreneurship. The present study also shows that the factors influencing the number of female entrepreneurs may be different from those influencing the share of female entrepreneurs. In this light it is important that governments are aware of what they want to accomplish (i.e., do they want to stimulate the number of female entrepreneurs or the gender composition of entrepreneurship) to be able to select appropriate policy measures.
\end{abstract}

Keywords: entrepreneurship, gender, determinants of entrepreneurship

Version: December 2005

JEL code: M13, H10, J16, J23 


\section{Explaining female and male entrepreneurship at the country level}

\section{Introduction}

Increasingly, female entrepreneurs are considered important for economic development. Not only do they contribute to employment creation and economic growth through their increasing numbers, they also make a contribution to the diversity of entrepreneurship in the economic process (Verheul and Thurik, 2001). Female and male entrepreneurs differ with respect to their personal and business profile: they start and run businesses in different sectors, develop different products, pursue different goals and structure their businesses in a different fashion (e.g., Fischer et al., 1993; Brush, 1992; Carter et al., 1997; Chaganti and Parasuraman, 1996; Verheul, 2003). Diversity in terms of products, processes, forms of organization and targeted markets is input for a selection process where customers are at liberty to choose according to their preferences and where entrepreneurs learn about what is viable from a technological and organizational perspective. This, in turn, may lead to a higher quality of entrepreneurship.

Despite the economic importance of female entrepreneurs, their number still lags behind that of male entrepreneurs. According to Reynolds et al. (2002) men are about twice as likely involved in entrepreneurial activity than women and Minniti et al. (2005) show that in all countries participating in the Global Entrepreneurship Monitor in 2004 men are more active in entrepreneurship than women ${ }^{1}$. However, there is substantial variation between countries. Table 1 presents female, male, and total entrepreneurial activity rates for 29 countries participating in the 2002 Global Entrepreneurship Monitor (GEM), ordered by female

entrepreneurial activity rate ${ }^{2}$. We observe that female entrepreneurship rates are high in some countries (e.g., India, Argentina, Brazil) and low in others (e.g., Japan, Belgium, Russia). Countries with high female entrepreneurial activity rates also tend to be characterized by high 
total entrepreneurial activity rates $^{3}$. According to Delmar (2003, p. 6): “women entrepreneurship is therefore closely related to the general framework conditions for entrepreneurship in a specific economy”.

Insert Table 1 about here

Insert Table 2 about here

In Table 1 female entrepreneurship is measured in absolute terms (i.e., counting numbers, scaled on population). However, as mentioned, female entrepreneurs are not only important because of their numbers, but also because of their contribution to the diversity of entrepreneurship in economies. In Table 2 female entrepreneurship is measured in relative terms (i.e., the share of women in the total number of entrepreneurs). This variable may be interpreted as a measure of entrepreneurial diversity, as it measures the contribution of women to a country's total stock of entrepreneurs (independent of the size of this stock). There are different countries at the higher end of the ranking in Table 2, as compared to Table 1. This indicates that it is important to make a distinction between measuring female entrepreneurship in absolute and relative terms ${ }^{4}$. Factors that contribute to a higher number of female entrepreneurs in a country may be different from those contributing to a higher diversity of entrepreneurship in the economy (as measured by the share of women in the stock of entrepreneurs $)^{5}$. Depending on the target pursued by policy makers, e.g., increasing absolute numbers or diversity, different policy measures may be used. Hence, it is important to investigate female entrepreneurship both as a share of the population and as a share of the total number of entrepreneurs. This paper investigates these two measures of female entrepreneurship separately. More specifically, we try to explain the variation between 
countries using both measures of female entrepreneurship. A variety of possible determinants will be considered.

Entrepreneurial activity in the present study corresponds with the Total Entrepreneurial Activity (TEA) rate as proposed in the Global Entrepreneurship Monitor (GEM). TEA is defined as the share of adults in the population of 18 to 64 years old who are either actively involved in starting a new business or in managing a business less than 42 months old (Reynolds et al., 2002, p. 5). Hence, this definition incorporates both nascent entrepreneurs and owner-managers of new firms. An individual is considered a 'nascent entrepreneur' under three conditions. First, an individual has taken action to create a new business in the past year. Second, the individual expects to share ownership of the new firm and, third, the firm has not yet paid salaries and wages for more than three months. A firm is considered a new firm in case salaries and wages are paid for more than three months but less than 42 months (Reynolds et al., 2002, p. 38). In this study entrepreneurial activity of women and men is represented by TEA for females and males, respectively. Entrepreneurial activity rates are derived from the GEM data set for 2002 and the macro-level determinants stem from standardized national statistics. We aim to draw conclusions from the way in which macrolevel factors explain female and male entrepreneurial activity rates.

Relatively few studies have investigated female entrepreneurship at the macro level, not to mention the difference in determinants of female and male entrepreneurial activity. The present study builds upon Kovalainen et al. (2002), who use GEM 2001 data for 29 countries, Reynolds et al. (2002, p. 25), who use GEM 2002 data for 37 countries, and Minniti et al. (2005), using data for 34 countries. Although these studies provide useful insights into the determinants of female and male entrepreneurial activity at the macro level, the present study develops a full model, explaining female and male entrepreneurial activity rates as well as the female share in entrepreneurship, and in which the interplay of economic, technological, demographic, institutional and cultural variables is accounted for. 
The explanatory variables are derived from three streams of literature. First, there is the literature on the determinants of entrepreneurship. A limitation of this literature (from the viewpoint of the present study) is that it only outlines general determinants of entrepreneurship. As we have argued, female entrepreneurship contributes to the diversity in entrepreneurship and this may imply that there are different factors explaining female and male entrepreneurship in a country. Indeed, investigating the involvement of the Swedish population in new venture creation, Delmar and Davidsson (2000) find that the factors explaining the nascent entrepreneurship rate of men have limited value in explaining the nascent entrepreneur status of women. Moreover, investigating differences in the reasons for firm start-up across country and gender, Shane et al. (1991) find that it is difficult to identify start-up reasons that equally apply to both genders and across countries. These studies show there is a need for country-level studies investigating the factors influencing female and male entrepreneurship in general, and their start-up rates in particular.

A second stream of literature investigates female participation in the labor force. Female participation in employment has increased considerably in the last decades, reflecting both changes in the labor supply behavior of women and the demand for female workers. Although the gender gap in employment is narrowing, employment rates (either in number of jobs or in number of hours worked) are still lower for women than for men in most OECD countries (OECD, 2002). Studies on female labor force participation create insight into the characteristics of women in the labor market, dealing with questions such as: what determines the decision of women to (re)enter the labor market, and to what extent do characteristics of the labor market, or the economic structure of a country offer opportunities for female workers?

The third literature is that on female entrepreneurship (or gender issues in entrepreneurship). Because the share of women in total entrepreneurial activity still lags behind the share of women in the labor force, and female entrepreneurship may be influenced by different factors 
than male entrepreneurship, we also pay attention to the female entrepreneurship literature (in addition to literature on female labor force participation and entrepreneurship in general). Women may have specific entrepreneurial capabilities and preferences as compared to men.

The literature on female entrepreneurship mainly consists of studies at the micro level, focusing on the distinctive characteristics of female and male entrepreneurs (e.g., motivations, personality traits, experience) or the features of their firms (e.g., size, goals and strategy, management, performance). Other studies have included environmental characteristics, such as financial constraints and other challenges that women face when starting or developing their firms. With the exception of Reynolds et al. (2002), Kovalainen et al. (2002) and Minniti et al. (2005) few studies have investigated the influence of macro-level factors on female and male entrepreneurship. The present study aims to extend this literature.

The structure of this paper is as follows. In Section 2, based upon a review of the literature, a list of determinants of entrepreneurship is proposed, distinguishing between technological development, economic factors, demographic factors, institutional (or policy) and cultural factors. These factors influence either the demand for entrepreneurship, through the number and type of entrepreneurial opportunities available, or the supply of entrepreneurship, through preferences and capabilities of individuals to become self-employed (Verheul et al., 2002). The influence of these factors on entrepreneurship in general will be discussed and we will give an a priori idea whether these factors have a differential impact on female and male entrepreneurship. Hypotheses are formulated in pairs, presenting (1) the influence of a factor on entrepreneurship in general, and (2) the differential impact of a factor on female and male entrepreneurship. Section 3 gives a description of the data and the variables used in the empirical analysis, including their sources. The main source is the Global Entrepreneurship Monitor database for $2002{ }^{6}$ 
In Section 4 the hypotheses are investigated using regression analysis. For each pair of hypotheses, the TEA rate (i.e., total, female, male) is the variable to be explained in the first (general) part of the hypothesis, while the female share in entrepreneurship is the variable to be explained in the second (gender) part. As an additional methodological exercise we compute regressions using gender-specific independent variables and compare the results with analyses using general variables (applying to both women and men). This exercise underlines the importance of systematic data collection by gender throughout the world. The chapter concludes with recommendations for further research and a discussion of policy implications.

\section{Determinants of Entrepreneurship and Gender Differences}

In this section we will deal with a range of determinants of entrepreneurship categorized according to the following five groups: technological development, economic factors, demographic factors, institutional factors and government intervention, and cultural factors (Verheul et al., 2002). Obviously, there is a large range of variables influencing (female) entrepreneurship. ${ }^{7}$ Since our analysis is based upon data of the GEM 2002 survey, the discussion in the present section is limited to the determinants of (female) entrepreneurship for which we have data available. From the viewpoint of the empirical analyses the number of explanatory factors should be restricted as the number of countries in our data set is limited.

\subsection{Technological Development}

New technologies have the potential to lead to the development of new products and services, creating opportunities for the start-up of new firms (Casson, 1995; Wennekers et al., 2002). In addition, new information and communication technologies lead to diminished transaction costs and lower minimum efficient scales in many industries, enabling small firms to compete in both new and established industries. Hence, it may be argued that small firms benefit from technological development, either directly (producing new products) or indirectly (making 
use of new production or communication techniques). Because women are less likely than men to operate businesses in high-technology sectors (Loscocco and Robinson, 1991; Anna et al., 1999), it may be expected that technological development is of less influence on female entrepreneurship than it is on male entrepreneurship. This leads to the formulation of the following hypotheses:

H1: Technological development has a positive influence on entrepreneurial activity ${ }^{8}$

H1a: Technological development has a larger influence on male than on female entrepreneurship.

\subsection{Economic Factors}

Per capita income

The influence of per capita income on entrepreneurship is complex as the development of a country's income level can be an indicator for several economic phenomena. For instance, economic development tends to be accompanied by rising real wages raising the opportunity costs of self-employment. This makes wage-employment more attractive (Lucas, 1978; EIM/ENSR, 1996). Indeed, several studies show a negative effect of economic development on self-employment (Kuznets, 1966; Schultz, 1990; Bregger, 1996). However, these studies refer mainly to the 1980s and earlier when per capita income levels are relatively low. The negative effect may reflect the exploitation of economies of scale in the post-World War IIperiod when the technological environment was relatively stable. Other, more recent, studies report a positive relationship between per capita income and entrepreneurship since the 1970s (Storey, 1999; Carree et al., 2002). From a certain level of economic development onwards, an increase in wealth tends to be accompanied by technological development and an increase in the size of the service sector, developments that -in turn- positively influence entrepreneurship. Combining the negative and positive effects results in a U-shaped 
relationship between per capita income (i.e., economic development) and entrepreneurship. Using several data sources on entrepreneurship, Carree et al. (2002) and Wennekers et al. (2005) provide empirical evidence for this U-shaped relationship. Both female and male entrepreneurial activity is expected to show a U-shaped relationship with per capita income. The following hypotheses are formulated:

H2: Income level has a U-shaped relationship with entrepreneurial activity. ${ }^{9}$

H2a: Income level has a U-shaped relationship with both female and male entrepreneurial activity $^{10}$

\section{Unemployment}

The relationship between unemployment and self-employment has been shrouded with ambiguity (Audretsch et al., 2005, p. 2). One may think of three different effects. First, there is the (positive) 'push' or 'refugee' effect of unemployment. At the micro level (the risk of) unemployment is likely to have a positive effect on the level of entrepreneurship through reducing the opportunity costs of self-employment. When there is little chance of finding paid employment unemployed people are 'pushed' into self-employment (EIM/ENSR, 1996). Hence, an increase in the level of entrepreneurial activity in a country does not always point at a stable economic situation. Tambunan (1992; 1994) finds evidence for the 'push' hypothesis as people in Indonesia tend to respond to income inequality and unemployment by starting or running small scale enterprises to have a source of income. In terms of the distinction between necessity and opportunity entrepreneurship as proposed in the Global Entrepreneurship Monitor (Reynolds et al., 2002), one may argue that increasing levels of unemployment are likely to lead to a higher level of necessity entrepreneurship (i.e., people who start a business because they have no other employment options available) relative to the level of opportunity entrepreneurship (i.e., people who start a business because they perceive an opportunity). 
Second, there is the (negative) 'Schumpeter' effect of more entrepreneurship leading to a decrease in unemployment. Not only do entrepreneurs hire employees, they also stimulate incumbent competitors to perform better leading to increased economic performance at a higher aggregation level. ${ }^{11}$

Using panel data of 23 OECD countries for the period 1974-2002, Audretsch et al. (2005) have been able to empirically distinguish between the 'refugee' and 'Schumpeter' effects described above. Their results confirm the existence of these two distinct relationships between unemployment and self-employment. They also find that the 'Schumpeter' (negative) effects are considerably stronger than the ‘refugee’ (positive) effects.

There is a third relationship between self-employment and unemployment. At the macro level a high rate of unemployment may be associated with a lower level of entrepreneurship as it may be an indication of a decrease in the number of business opportunities induced by a depressed economy.

Because there are both positive and negative relationships, it comes as no surprise that empirical evidence on the relationship between entrepreneurship and unemployment has been mixed. However, reviewing the early empirical evidence that related unemployment rates to new-firm start-up activity, Storey (1991, p. 177) concludes that: “The broad consensus is that time series analyses point to unemployment being, ceteris paribus, positively associated with indices of new-firm formation, whereas cross sectional, or pooled cross sectional studies appear to indicate the reverse.” In our study we use a cross sectional data base. Therefore, based on the review by Storey (1991) and the more recent results by Audretsch et al. (2005), we expect the negative effects to dominate.

The unemployment level may be more likely to (negatively) affect female than male employment as women are often involved in service-type and part-time jobs and, accordingly, may be particularly vulnerable to the effects of unemployment. Indeed, Lin et al. (2000) find 
that the self-employment rate of women is more negatively responsive to unemployment than the male self-employment rate ${ }^{12}$. We formulate the following hypotheses:

H3: Unemployment has a negative effect on entrepreneurial activity (at the macro level).

H3a: Unemployment has a larger effect on female than on male entrepreneurship.

Share of the service sector

An expansion of the service sector tends to positively influence entrepreneurship. The service sector is characterized by low initial capital requirements, leading to low barriers to entry and facilitating start-up. Most services are characterized by a relatively small average firm size (EIM/ENSR, 1997). The growth of service industries has also been a major factor in increasing female labor force participation (Oppenheimer, 1970; Ward and Pampel, 1985). Because women are over-represented in the service sector, a higher share of services may be more likely to influence female than male entrepreneurship ${ }^{13}$. This leads to the following hypotheses:

H4: The share of service sector employment has a positive influence on entrepreneurial activity.

H4a: The share of service sector employment has a larger influence on female than on male entrepreneurship.

Informal sector

The informal sector (i.e., shadow or underground economy) has been referred to as economic activities that are not registered in the national accounts and are not subject to formal rules of contract, licensing, labor inspection, reporting and taxation (ILO, 1984). People may engage in informal activity because of different factors, such as poverty, unemployment, or tax evasion. The reasons to engage in informal activity may be different for developed and 
underdeveloped economies. For instance, firms in poor countries tend to face a higher regulatory burden than those in rich countries. Hence, business owners in less developed countries may be more reluctant to register their firms and more likely to operate in the informal economy (World Bank, 2005, p. 3).

The size of the informal sector may negatively influence entrepreneurial activity as people operating in the informal sector absorb (entrepreneurial) opportunities otherwise available for starting a business in the formal sector ${ }^{14}$. The size of the informal sector may differentially impact female and male entrepreneurship. For instance, informal sector activity may appeal to women since it is a relatively easy, often 'close-to-home' manner to earn an additional income, especially when there are no part-time jobs available. Because women still take on the bulk of activities within the household, they have to divide their time between household and work activities. Hence, informal activity and (formal) entrepreneurial activity may be alternative ways for women to realize greater flexibility to combine work and household activities. The following hypotheses are formulated:

H5: The size of the informal sector has a negative influence on (formal) entrepreneurial activity.

H5a: The size of the informal sector has a larger influence on female than on male entrepreneurship (in the formal sector).

Female labor force participation

A higher share of women in the labor force is likely to be accompanied by a lower level of self-employment (as a percentage of labor force), as women are less likely than men to become self-employed. Delmar and Davidsson (2000) find that gender is a strong predictor of nascent entrepreneurship at the micro-level, with men being more likely to have the intention to start a business than women. Uhlaner et al. (2002) find that countries with a higher female 
share in the labor force are characterized by a lower level of self-employment. Uhlaner et al. (2002) measure self-employment as a percentage of the labor force. However, the entrepreneurial activity rate used in the present paper is scaled on population. As a higher female labor share (share of women in total labor force) is generally associated with higher female labor force participation (female labor force as a share of female population), a positive impact of female labor share on female entrepreneurial activity may be expected ${ }^{15}$. Hence, even though women tend to be wage-employed rather than self-employed, higher female labor shares are expected to be associated with higher female entrepreneurial activity rates, simply because the supply of female workers is larger. We do not expect female labor force participation to influence male entrepreneurship. As the TEA rate is an average of female and male entrepreneurial activity, the general effect may be expected to be positive but stronger for female entrepreneurial activity. The following hypotheses are formulated:

H6: Female labor force participation has a positive influence on entrepreneurial activity. ${ }^{16}$

H6a: Female labor force participation has a positive influence on female entrepreneurship and no influence on male entrepreneurship.

\section{Economic transition}

The economic structure of former communist (or transition) countries differs from that of non-transition countries. In centrally planned economies entrepreneurial activity was limited as the emphasis was on economies of scale and the business culture did not support innovation and entrepreneurship (Roman, 1990; Mugler, 2000). During the transition process small firms start replacing the larger industrial businesses and there is a shift away from unskilled, labor-intensive production towards capital-, technology- and skill-intensive production (Brunner, 1993). However, the development of entrepreneurship in most transition countries still lags behind that of non-transition countries. ${ }^{17}$ This is because the business environment in transition countries is less favorable than in most non-transition economies. 
Transition economies tend to be characterized by a relatively unstable economic environment, a low domestic purchasing power and uncertainty with respect to property rights (Smallbone and Welter, 2001). Other impediments to entrepreneurship in transition economies as described by Mugler (2000) include a shortage of entrepreneurial and management skills; underdevelopment of the regulatory system, bureaucratic and time-consuming registration; need for modernization of infrastructure and communication network, limited access to capital and limited knowledge and organization of market services.

It should be noted though that the transition effect on entrepreneurship is likely to differ between transition countries, depending upon the phase and pace of the reforms (Smallbone and Welter, 2001; Mugler, 2000). However, as we compare transition and non-transition countries we will not take into account the diversity within the latter group of countries.

The transition effect may be stronger for women who are twice as less likely to become entrepreneurs than men (UNECE, 2002). Although self-employment in the form of crossborder trade, street trade or subcontracting work at home is a much pursued avenue of employment for women in transition countries, at the same time they experience genderrelated barriers with respect to access to information, networks and collateral (RuminskaZimny, 2002). Hence, it is expected that there is a negative effect of economic transition on entrepreneurship, which may be larger for female than for male entrepreneurship. This leads to the following hypotheses:

H7: Former communist (or transition) countries are characterized by lower levels of entrepreneurial activity than non-transition countries.

H7a: Economic transition has a larger influence on female than on male entrepreneurship. 


\subsection{Demographic Factors}

Family situation

The role of the family within society has changed dramatically in the last decades with a lower marriage rate, postponed marriages, an increasing divorce rate and lower birth rates. According to Mincer (1985) declines in average family size and in the duration of marriage provide an increased scope and motivation for female labor force participation. However, although women are increasingly entering the work force, they are still more likely to be the “primary parent, emotional nurturer and housekeeper” (Unger and Crawford, 1992, p. 474) ${ }^{18}$. OECD (2002) finds that the presence of children influences the employment rates of women and men in opposite directions: parenthood negatively influences female employment, while positively influencing male employment. Mothers are less likely to be full-time employed than women without children. Hence, family situation (e.g., marriage and children) may have a differential effect on the entrepreneurship of women and men. With respect to the impact of family on entrepreneurship in general, it may be argued that if the head of the household is responsible for maintaining the family, he or she is likely to choose wage-employment over self-employment, because the former involves less risk. The following hypotheses are formulated:

H8: The importance of family has a negative influence on entrepreneurship.

H8a: The importance of family has a larger influence on female than on male entrepreneurship.

Other demographic factors also play a role at the supply side of entrepreneurship. Several linkages have been identified between self-employment and demographic factors, including age, ethnicity, education level, gender and previous experience in self-employment (Cooper and Dunkelberg, 1987; Evans and Leighton, 1989; Delmar and Davidsson, 2000; Erutku and 
Vallée, 1997, Reynolds, 1997, Grilo and Thurik, 2005a) ${ }^{19}$. Because we work with the GEM 2002 data set, which does not have information on all of these demographic factors, no hypotheses are formulated for these factors.

\subsection{Institutional Factors and Government Intervention}

Verheul et al. (2002) distinguish between different ways for the government to influence the rate of entrepreneurship. On the demand side the government can influence both the number and accessibility of entrepreneurial opportunities through investments in $R \& D$, privatization, income policy (number), competition policy, (de)regulation, fiscal incentives, labor market regulation, and establishment and bankruptcy policy (accessibility). On the supply side the government can influence capabilities and preferences of individuals to become selfemployed through access to finance, social security ${ }^{20}$, information provision and introducing aspects of entrepreneurship ${ }^{21}$ in the educational system. The government can also create a mindset for entrepreneurship through paying attention to entrepreneurship in the media. Most of these factors are expected to have a similar impact on female and male entrepreneurial activity as they are generic factors influencing the general entrepreneurial climate. The following institutional factors may have a differential impact on female and male entrepreneurship.

\section{Business licensing}

Business licensing may be a barrier for (potential) entrepreneurs as it raises the costs of starting or running a business. These costs can take different forms. The World Bank (2005) distinguishes between costs associated with starting a business, hiring and firing, registering property, enforcing contracts, getting credit, protecting investors and business closure. Complying with business regulations in these different areas consumes time and money, especially when these procedures are complex and not transparent. Government reform in 
these areas may lead to more economic growth because entrepreneurs spend less time and money on dealing with such regulations and use their energy in more productive ways, focusing upon the main production process (World Bank, 2005, p. 5). Simplification of, for example, establishment legislation diminishes the costs involved in starting up a business and may stimulate people to start a firm (OECD, 1998).

There are still fewer women than men who start up and run small firms. On average female entrepreneurs tend to have less previous experience with starting or running a business (Fischer et al., 1993; Kalleberg and Leicht, 1991) and, accordingly, may have more difficulty with or spend more time on coping with business regulation. The following hypotheses are formulated $^{22}$ :

H9: Entry regulation has a negative impact on entrepreneurship.

H9a: Entry regulation has a larger impact on female than on male entrepreneurship.

\section{Availability of capital}

The availability of capital is important for entrepreneurship as it lays the foundation for the business (Cressy, 2002). Acquiring financial capital has often been referred to as an important problem for entrepreneurs (Hughes and Storey, 1994). Entrepreneurs engaged in new venture activity usually have little equity to finance their business with, while debt and (external) equity is difficult to acquire. Financial institutions tend to be reluctant to lend money to earlystage and seed businesses because of the high risks involved, the lack of a track record, the lack of information available on the profitability of small firms and the fixed cost element of transactions (Berger and Udell, 1998; Chittenden et al., 1996; Cressy, 2005). Informal venture capital (provided for by business angels) may be a fruitful alternative to more formal venture capital for entrepreneurs starting up or running small businesses, although venture capitalists may also have a preference for the high-growth firms (Cressy, 2005). 
Assuming equal availability of capital for female and male entrepreneurs, there may be gender-related barriers to acquire it. Women may have more problems securing finance through the regular channels because their business profile usually is less favorable for investors than that of men, with women starting smaller businesses, in services and often working part-time (Verheul and Thurik, 2001). Several studies suggest that acquiring capital is more difficult for women than for men, and that women have more difficulty in convincing (potential) investors (Schwartz, 1976; Hisrich and Brush, 1986; Brush, 1992; Carter and Cannon, 1992; Carter, 2000) ${ }^{23}$. Hence, the availability of (in)formal capital may be more likely to affect female than male entrepreneurship. The following hypotheses are formulated for the availability of informal venture capital ${ }^{24}$ :

H10: The availability of informal venture capital has a positive influence on entrepreneurship.

H10a: The availability of informal venture capital has a larger impact on female than on male entrepreneurship.

\section{Child care and parental leave}

Because women are still responsible for the major part of child-rearing activities, the availability and price of child-care facilities will influence female employment. If quality child-care is unavailable or costly, more women are likely to discontinue employment or refrain from re-entering the labor market when they become mothers. In addition to privately provided day-care, subsidies for child-care or arranging for subsidized parental leaves can stimulate female labor force participation. Gustafsson and Jacobsson (1985) argue that in countries with less generous parental leave schemes, more working mothers give up their jobs. Indeed, Kovalainen et al. (2002) find a negative relationship between maternity leave and the start-up rate of women ${ }^{25}$. However, it should be borne in mind that whereas parental leave schemes usually are available for wage-employed people, the availability of these 
facilities is limited for the self-employed. When generous maternity leave schemes are available for wage earners, wage-employment is more attractive vis-à-vis self-employment and people are less willing to give up their wage jobs to start a business. The availability of these schemes in wage-employment is expected to have a greater (negative) impact on female than on male entrepreneurship as child-rearing activities are a constraint particularly for working women.

H11: The availability of maternity leave schemes negatively influences entrepreneurship.

H11a: The availability of maternity leave schemes has a larger influence on female than on male entrepreneurship.

\subsection{Cultural Factors}

Cultural values play a role in shaping the institutions in a country. Values and beliefs shape behavior and, accordingly, may be assumed also to influence the decision to become selfemployed (Mueller and Thomas, 2000) ${ }^{26}$. Entrepreneurial culture is a complex concept, bundling many aspects, including the recognition that is given to entrepreneurs, the prevailing attitudes towards success and failure and the degree to which people regard the pursuit of opportunities as socially legitimate (Reynolds et al., 1999). More deeply rooted cultural values can also be linked to entrepreneurship. Hofstede $(1980,2001)$ distinguishes between several cultural indicators, including power distance, individualism, masculinity, uncertainty avoidance and long-term versus short-term orientation.

\section{Dissatisfaction}

The relationship between cultural factors and entrepreneurship is dependent upon whether this relationship is viewed from the aggregate psychological traits or the social legitimation (dissatisfaction) perspective (Davidsson, 1995; Wennekers et al., 2002; Hofstede et al., 2004). The aggregate psychological trait explanation of entrepreneurship argues that if there are 
more people with entrepreneurial values in a country, there are also more entrepreneurs. According to the social legitimation perspective entrepreneurship is influenced by the difference in values and beliefs between the population as a whole and potential entrepreneurs. When individuals are dissatisfied with existing structures (which do not offer them entrepreneurial opportunities), they are likely to leave the mainstream organizations and start their own business (Baum et al., 1993; Etzioni, 1987). Empirical evidence on the relationship between dissatisfaction and entrepreneurship at the country level is scarce, partly because of a lack of data. However, using data for 15 European countries for the period 19782000, Noorderhaven et al. (2004) find a positive effect of dissatisfaction (with life) on selfemployment levels, supporting the social legitimating perspective.

Gender of the entrepreneur may play a role in the relationship with culture. From an aggregate psychological traits perspective it can be argued that women are less likely to possess entrepreneurial traits and, accordingly, are less likely to become entrepreneurs. With respect to the social legitimating perspective both women and men are confronted with social and organizational structures that do (not) offer entrepreneurial opportunities, motivating them to start their own firm. Vroom (1982) shows that there is often a positive relationship between life and job satisfaction. People who are dissatisfied with their job also tend to be dissatisfied with life. Brayfield et al. (1957), as cited in Vroom (1982), argue that men who are dissatisfied with their jobs, are more likely to be dissatisfied with life in general than women who are experiencing job dissatisfaction ${ }^{27}$. Accordingly, we may expect that men who are dissatisfied (with their jobs) are more likely to come into action and start their own business than women who are dissatisfied. From this perspective dissatisfaction with life is expected to have a larger impact on male than on female entrepreneurship. The following hypotheses are formulated:

H12: Dissatisfaction with life positively influences entrepreneurship. ${ }^{28}$ 
H12a: Dissatisfaction with life has a larger influence on male than on female entrepreneurship.

\section{Data Analysis and Variable Description}

The hypotheses are investigated using regression analyses. The following criteria are applied to accept hypotheses. For the general hypotheses, the impact of a variable on the entrepreneurial activity rate should be significant at the 5 percent level. As all of our hypotheses are in a specific direction, we use one-tailed tests. For the gender hypotheses two conditions have to be met. First, the impact of a variable on the female share in entrepreneurship has to be significant at the 5 percent level, with the predicted sign (i.e., in a one-tailed test). Second, the sign of the effect on total entrepreneurial activity should correspond with that in the general hypothesis.

Table 3 presents a list of dependent and independent variables used in this study, including their sources.

Insert Table 3 about here

\section{Results}

We start this empirical analysis with a simple correlation analysis. Subsequently, to test the general hypotheses, we estimate regression models explaining total entrepreneurial activity rates of women and men (Regression Analysis I). This is followed by a regression analysis explaining the female share in entrepreneurship to test the gender hypotheses (Regression Analysis II). Finally, as a separate exercise, we investigate the extent to which using genderspecific instead of general independent variables influences estimation results (Regression Analysis III). 


\subsection{Correlation Analysis}

\section{Correlation between dependent and independent variables}

Table 4 reports the means, standard deviations and correlation coefficients of the major variables in this study. From Table 4 we see that a large number of the independent variables are significantly related to the major dependent variable, i.e., female entrepreneurial activity. In particular, the following variables are significantly correlated with female entrepreneurship: female labor share $(r=-0.59, p<0.01)$, per capita income $(r=-0.48, p<0.01)$, informal sector ( $r=0.48, p<0.01)$, importance of family $(r=0.40, p<0.05)$, R\&D investments $(r=-0.39, p<0.05)$, informal venture capital $(r=0.38, p<0.05)$ and squared per capita income $(r=-0.38, p<0.05)$.

Insert Table 4 about here

Considering the hypotheses formulated earlier, there are two striking observations: both the size of the informal sector and the female labor share have a highly significant correlation with female entrepreneurial activity with a sign opposite to what we expected. For the informal sector we find a positive sign (where we expected a negative one), and for female labor share we find a negative sign (where we expected a positive one).

Closer inspection of the data reveals that a small number of developing countries (India, Argentina, Brazil and Mexico) is responsible for these counterintuitive correlations. These four countries have the highest female entrepreneurial activity rates (see Table 1) and combine these high rates with both a relatively large informal sector (together with Russia these four countries are the top five $)^{29}$ and a low share of women in the labor force. Excluding the four countries (i.e., using 25 observations) the partial correlation of the female 
entrepreneurship rate with both the size of the informal sector and the female labor share is -0.18 , and both correlations are not significant.

The four countries also are among the six countries with the highest female share in entrepreneurship (see Table 2). This observation is consistent with the argument that particularly women may be involved in informal activities ${ }^{30}$ as discussed in Section $2^{31}$. In fact, the four countries are the only ones in our data set for which the share of women in entrepreneurial activity is higher than the share of women in the labor force. As the latter variable is taken from official statistics (from national bureaus of statistics), it is not inconceivable that (female) entrepreneurs in the informal sector are not counted in the labor force measure, but are included in the TEA measure of $\mathrm{GEM}^{32}$.

Given the specific pattern for India, Argentina, Brazil, and Mexico (i.e., high entrepreneurial activity rates, large informal sector, low female labor share), we consider it likely that for these countries a substantial number of entrepreneurs measured in the TEA rate are ownermanagers of unofficial businesses, i.e., they are part of the informal sector. The above observations should define an important topic for the Global Entrepreneurship Monitor research agenda that has been largely unexplored up till now: how many 'informal' entrepreneurs are included in the entrepreneurship measures of the Adult Population Survey, and how does this affect empirical analyses that make use of the GEM data base? This issue is important in particular for studies focusing on GEM countries with large informal sectors.

\section{Correlations between the dependent variables}

As can be seen from Table 4 the correlations between the dependent variables total, female and male entrepreneurial activity are very high. Accordingly, we may expect that the determinants of total, female and male entrepreneurial activity are similar rather than different. 


\section{Correlations among independent variables}

With respect to the independent variables, we observe high correlations between $R \& D$ investments, per capita income (squared), and informal sector. The high positive correlation between R\&D investments and per capita income $(r=0.81, p<0.01)$ implies that, ceteris paribus, rich countries invest more in R\&D than poor countries. The high negative correlation between per capita income and informal sector $(r=-0.81, p<0.01)$ may be explained by the fact that poorer countries are likely to have a large informal sector, where people without a formal job search other (informal) means to earn a living. Life satisfaction is correlated with several other explanatory variables, including per capita income $(r=0.64, p<0.01)$, service sector employment ( $r=0.57, p<0.01), \mathrm{R} \& \mathrm{D}$ investments $(r=0.56, p<0.01)$, economic transition or communism ( $r=-0.56, p<0.01)$, unemployment $(r=-0.50, p<0.01)$, and informal sector $(r=-$ $0.49, p<0.01)$. Hence, ceteris paribus, in richer, more stable countries people are more satisfied. The finding that unemployment is negatively related to life satisfaction is in accordance with Vroom (1982). Also, entry regulation is correlated with R\&D investments $(r=-0.48, p<0.01)$, per capita income $(r=-0.48, p<0.01)$, service sector employment $(r=-0.52$, $p<0.01)$ and per capita income squared $(r=-0.56, p<0.05)$, which indicates that richer and more developed countries are characterized by less entry regulation (e.g., World Bank, 2005).

\subsection{Regression Analysis I: Explaining Entrepreneurial Activity Rates}

To investigate the determinants of the number of entrepreneurs in a country, regression analyses are performed explaining total, female and male entrepreneurial activity (i.e., the sum of nascent entrepreneurs and owner/managers of new firms, as a percentage of adult

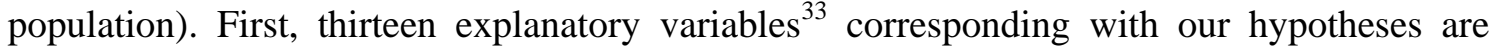
included. The number of explanatory variables is high considering the number of observations, i.e., 29 countries. In particular, the high number of explanatory variables may 
hamper interpretation of the regression results because of potential multicollinearity. Therefore, we also present the results of a general-to-specific modeling procedure on total, female and male entrepreneurial activity including variables with a significant effect only (see Bleaney and Nishiyama, 2002). ${ }^{34}$ An additional advantage of this modeling procedure is that it enables us to investigate whether female and male activity is influenced by different factors. With respect to the influence of per capita income, the aim is to test for a U-shaped effect (see H2). Accordingly, in the general-to-specific modeling procedure we have included both the per capita income and the squared per capita income variable, irrespective of their significance level. Results are presented in Tables 5 and 6.

Insert Table 5 about here

Insert Table 6 about here

From Table 5 we see that several variables influence total entrepreneurial activity in a country, including R\&D investments, per capita income, female labor share, importance of family and informal venture capital. ${ }^{35}$

The negative effect of $R \& D$ investments on total and male entrepreneurial activity is in contradiction with Hypothesis 1. High investments in R\&D may be an indicator of the presence of large firms, which usually invest more in $R \& D$ than small businesses and tend to be more aware of their R\&D investments and more willing to report on them. Indeed, Jacobsson et al. (1996) argue that the use of R\&D data to measure technological activities may lead to an underestimation of these activities in smaller firms as these firms are less likely to report expenditures on R\&D. Also, R\&D investments may be considered an input variable, which does not guarantee innovative output. Finally, the relationship between 
technological development and entrepreneurship may be non-linear. Assuming a U-shaped relationship ${ }^{36}$, it may be argued that many of the less developed countries included in the empirical study are still in the 'Schumpeter II' phase (declining end of the U-shape) where the technological regime fosters economies of scale and scope, thereby reducing opportunities for small firms.

With respect to per capita income, there is some indication of a U-shaped relationship, where per capita income has a negative effect on entrepreneurial activity and the impact of per capita income squared is positive (although only significant for female entrepreneurial activity). Although the findings do not provide full support for Hypothesis 2 (due to the low levels of significance), it does indicate that the existence of a U-shaped relationship between income level and entrepreneurship is not imaginary. This U-shaped relationship is also in accordance with findings by Carree et al. (2002) and Wennekers et al. (2005).

The level of unemployment does not have a significant effect on total and female entrepreneurial activity, but it does seem to have a negative influence on male entrepreneurial activity. Hence, there is some indication of a differential effect of unemployment on female and male entrepreneurial activity. At least for male entrepreneurial activity the negative effect of unemployment outweighs the positive 'refugee' effect, where a decrease in the number of entrepreneurial opportunities cancels out the positive impact of unemployment as a push factor. However, as pointed out earlier, the negative effect may also be caused by a 'Schumpeterian effect' of more entrepreneurship leading to increased employment. Hypothesis 3 is partly supported.

The share of the service sector and that of the informal sector do not have a significant influence on entrepreneurial activity. Hypotheses 4 and 5 are not supported. As opposed to what is predicted in Hypothesis 6 the female labor share has a negative influence on entrepreneurial activity. As explained in Section 4.1, we suspect that this result is due to the 
large numbers of (female) entrepreneurs in the informal sector in developing countries such as India, Brazil, Mexico and Argentina.

The effect of former communist country is negative but not significant. Hence, there is no support for Hypothesis 7. Moreover, contrary to Hypothesis 7a this variable seems to influence male entrepreneurial activity rather than female entrepreneurial activity (see Table 6). Again, high numbers of female entrepreneurs in the informal sector in these countries may explain the non-significant result for female entrepreneurial activity. In contrast with Hypothesis 8 the importance of family (i.e., high family values) positively influences entrepreneurial activity. Because entrepreneurship involves high risk and time investments, it is often argued that entrepreneurship is not a 'viable' option for people who run a household and have high family values. However, self-employment may also enable household members to adjust time schedules to family needs because there is more flexibility in working hours. In addition, family support and the possibility to work from the home may also play a role.

Informal venture capital has a significant positive effect on entrepreneurial activity. Hypothesis 10 is supported. Entry regulation, maternity leave coverage and life satisfaction do not seem to influence entrepreneurial activity ${ }^{37}$. Hypotheses 9, 11 and 12 are not supported.

The results in Table 6 provide evidence that female and male entrepreneurial activity are at least to some extent influenced by different factors. For example, investments in R\&D and unemployment seem to influence male entrepreneurial activity rather than female entrepreneurial activity. Also, this seems to be the case for former communist country and informal sector. On the other hand, life satisfaction seems to influence female entrepreneurial activity only. But even if a factor influences both male and female entrepreneurial activity, its relative impact may still be different. In the next section we test for possible differential effects of the explanatory variables on female and male entrepreneurial activity by means of a regression analysis explaining the female share in entrepreneurial activity. 


\subsection{Regression Analysis II: Explaining the Female Share in Entrepreneurship}

In the previous section we investigated determinants of the number of female and male entrepreneurs in a country (scaled on population). However, we are also interested whether certain variables influence female and male entrepreneurship differently. In other words, what determines the composition or diversity of entrepreneurship in a country? Using the outcomes in Tables 5 and 6 is not appropriate for investigating the determinants of the diversity of entrepreneurship as the coefficients in this table refer to absolute numbers of entrepreneurs and the coefficients in regressions explaining the number of male entrepreneurs are generally larger than those in regressions explaining the number of female entrepreneurs. This can be attributed simply to the fact that there are more male than female entrepreneurs (see Table 1). Accordingly, from Tables 5 and 6 we cannot read whether the relative impact of variables is different for female and male entrepreneurship.

To investigate differential effects on female and male entrepreneurship, we make use of a regression explaining the female share in total entrepreneurial activity including the explanatory variables that have a significant impact on either female or male entrepreneurial activity in Table 6 (i.e., leaving out service sector employment, entry regulation and maternity leave coverage $)^{38}$. Results are presented in Table 7 . Note that to correctly interpret and understand the differential effects, the results in Table 7 should be studied alongside the findings in Tables 5 and 6. More specifically, a positive effect on the female share of entrepreneurs may be interpreted in two different ways: a variable may either have a (relatively) larger positive or a (relatively) smaller negative effect on female entrepreneurship (as compared to male entrepreneurship). Which of these two effects occurs can be deduced from Tables 5 and 6.

Insert Table 7 about here 
From Table 7 we see that only two factors (unemployment and life satisfaction) influence the female share in entrepreneurship. The effect of unemployment is positive. This means that the negative effect of unemployment on entrepreneurial activity is (significantly) smaller for women than for men (see Table 5), which is opposite to what is predicted in Hypothesis 3a. It may be that the positive (push) effect of unemployment is larger for women than for men, i.e., women are more likely to start a business out of necessity in a situation of economic recession than men. Indeed, Reynolds et al. (2002) find that, although men are more likely to be involved in entrepreneurial activity, the difference in the entrepreneurial activity rate of men and women is smaller for 'necessity' than for 'opportunity' entrepreneurship.

We also find a positive effect of life satisfaction. This has to be interpreted as a positive effect of life satisfaction on female entrepreneurship, while such an effect is non-existent for male entrepreneurship (see Table 5). Note that this is in contradiction with Hypothesis 12a. This result may be explained by the fact that, as compared to men, women tend to be more driven by emotions, i.e., they make more intuitive decisions. Accordingly, for women it may be more important that they feel confident (about themselves and the environment) before they decide to start a business. For men the decision to start a business may be less dependent on their emotional wellbeing. ${ }^{39}$ For the remaining variables no effects on the female share in entrepreneurship are found.

The significant effect of life satisfaction in Table 7 again demonstrates that studying the number of entrepreneurs and the composition or diversity of entrepreneurship is not comparable as Tables 5 and 7 report different $t$-values. While in Table 7 the coefficient of life satisfaction is highly significant, in Table 5 the coefficients of life satisfaction have low $t$ values $^{40}$. It also demonstrates the importance of applying a full model where the interplay of variables is accounted for. Note that in Table 4 the direct correlation coefficient between female share in total entrepreneurial activity and life satisfaction is only 0.01 . 


\subsection{Size of Effects}

Previous sections investigating the (difference in the) determinants of female and male entrepreneurship mainly focused on the significance and the sign of the estimated effects in the various regressions. However, we are also interested in the size of the effects. To what extent does TEA or the female share in TEA change if one of the explanatory variables changes by a given amount? And which variables have the largest impact? Because of differences in measurement unit these questions can not be answered by comparing the coefficients of the various explanatory variables. For instance, some variables are measured in percentages, while others are measured using a Likert scale (see Table 3).

To compare the effects and obtain an impression of the extent to which TEA or the female share in TEA can be influenced by a plausible change of an explanatory variable, we computed the ceteris paribus effect of an increase of one standard deviation for each explanatory variable with a significant impact on either female or male entrepreneurial activity in Table 6. As there is high variation in per capita income between the countries in our data set (ranging from 2,450 US\$ for India to 34,870 US\$ for the United States) an impulse of one standard deviation (or 8,960 US\$, see Table 4) cannot be considered plausible. Therefore we compute the effect of an impulse in per capita income of 2,000 US\$. Results are presented in Table 8.

Insert Table 8 about here

From the perspective of gender differences (i.e., an effect on the female share) again unemployment and life satisfaction stand out. This is comparable to the findings in Table $7 .{ }^{41}$ A one standard deviation increase of a country's score on life satisfaction has a positive effect of 0.85 on female TEA, while it has no effect on the number of male entrepreneurs. Given the larger number of male entrepreneurs, this implies a considerable effect on the female share in 
entrepreneurship. Indeed, from the last column in Table 8 we see that the effect is 3.58 percent point. Unemployment has a negative effect (of 1.58 percent point) on the male TEA rate and no effect on the female TEA rate, and there is a positive effect of 2.51 percent point on the female share in total entrepreneurial activity.

\subsection{Regression Analysis III: Introducing Gender-Specific Independent Variables}

The analyses presented above make use of explanatory variables that are similar for women and men. However, it may be argued that the explanation of female and male entrepreneurial activity rates can be improved by using gender-specific independent variables. For instance, explaining the variation in female entrepreneurial activity across countries, the female unemployment rate is more relevant than the general unemployment rate (i.e., aggregate of women and men). However, variables that are separately available for women and men for a large number of countries are scarce. Nevertheless, in this section we attempt to explain female and male entrepreneurship rates by way of gender-specific independent variables. Again we present both a correlation and a regression analysis.

Gender-specific data for the 29 countries are available for unemployment, service sector employment, importance of family and life satisfaction ${ }^{42}$. These gender-specific variables will be included in the regression analysis, in addition to the general variables used in previous analyses. Measurement and rating categories are in accordance with the general variables used in the previous analyses (see Table 3). Table 9 presents the correlations among the genderspecific variables, also including TEA rates for women and men. Moreover, the means and standard deviations of the gender-specific variables are presented.

Insert Table 9 about here 
From Table 9 it can be seen that the only variable related to TEA female and TEA male is the importance of family for men. Importance of family for women is not significantly related to entrepreneurial activity. In Table 4 we have seen that importance of family is correlated with both TEA female $(r=0.40, p<0.05)$ and TEA male $(r=0.45, p<0.05)$, (erroneously) suggesting that this relationship is valid for women and men. Using gender-specific explanatory variables appears to be important for adequate interpretation of the relationships.

The correlation of importance of family for men with both TEA female and TEA male suggests that when men consider family to be more important, this leads to an increase in both female and male entrepreneurial activity. There is no such crosswise effect for the importance of family for women. It may be argued that if men regard family as important, they become self-employed (enabling them to work flexible hours and/or from the home) and their wives also start working in the business as unpaid family worker. This may not be true for women who become self-employed, i.e., husbands may be more likely to keep their own job instead of contributing or assisting in the spouse's firm, explaining the absence of an effect of importance of family for women on male entrepreneurial activity.

Results of the regression analyses explaining TEA female and TEA male, using both general and gender-specific data, are presented in Tables 10a and 10b, respectively. The genderspecific independent variables are indicated in bold. For ease of comparison we also present the results of Table 5 (including general explanatory variables only) in both tables.

Insert Table 10a about here

Insert Table 10b about here 
Comparing the results in Tables 10a and 10b (including gender-specific explanatory variables) to those in Table 5 (including general explanatory variables only) we see that the explanatory value of the model, measured by (adjusted) $R^{2}$, increases for TEA female while it decreases for TEA male, albeit marginally. Hence, it seems that including gender-specific variables is more important for understanding female entrepreneurial activity than it is for male entrepreneurial activity.

Including gender-specific variables strengthens the effects of several other explanatory variables on female entrepreneurial activity (Table 10a). In particular, the U-shaped relationship of per capita income with TEA female has become more pronounced. This effect can be explained by the fact that modern economies (with a higher per capita income) are generally characterized by a higher share of services and, given their higher prevalence in services, by more female entrepreneurs. This is consistent with the steeper upward part of the curve, as expressed by the larger coefficient for squared per capita income in the analysis including gender-specific variables. Furthermore, the effects of the gender-specific variables as well as R\&D investments and "former communist country" appear to be somewhat more significant (vis-à-vis the analysis including general variables only). For male entrepreneurial activity the largest effect of including gender-specific variables is for former communist country (Table 10b).

The analysis presented above illustrates that it is important to use gender-specific variables when explaining the (differences between) female and male entrepreneurship. Including gender-specific variables may not only alter coefficients of (some of) these gender-specific variables, but also those of several general variables. The influence on the effect of the general variables is due to the interplay between explanatory variables in regression models. Furthermore, from the correlation analysis we have seen that there may also be crosswise effects, i.e., a male variable influences the number of female entrepreneurs or vice versa. The availability of more gender-specific data is required to further explore these crosswise effects. 
In sum, more systematic collection of gender-specific data may have an important contribution in creating a better understanding of the determinants of male and female entrepreneurship.

\section{Discussion and Conclusion}

Corresponding with the hypotheses and using one-tailed test procedures, the present study finds significant effects on entrepreneurial activity rates of per capita income, unemployment, informal sector, former communist country and informal venture capital. We find differential effects on female and male entrepreneurial activity for unemployment and life satisfaction. More specifically, the negative effect of unemployment is smaller for women and the effect of life satisfaction on entrepreneurial activity is positive for women and non-existent for men.

The present paper has an important conceptual and empirical contribution, in particular since there have been relatively few studies focusing upon the determinants of female and male entrepreneurial activity at the country level. From a conceptual perspective the present paper brings together several streams of literature and discusses the influence on (female) entrepreneurship of a large range of factors that are classified into five focal areas (i.e., technological, economic, demographic, institutional and cultural factors). From an empirical viewpoint this study shows the methodological implications of studying the determinants of female and male entrepreneurial activity. We argue that there are different ways to measure female entrepreneurship at the macro-level (i.e., in absolute or relative terms) and show that a distinction can be made between including general or gender-specific explanatory variables in the analysis. Moreover, developing a full regression model where the interplay of variables is accounted for may be more suitable for understanding the origin of female and male entrepreneurship than merely investigating direct correlations. 
With respect to the link between theory and the empirical analysis it should be noted that most of the literature we refer to in this study focuses upon the Anglo-Saxon countries and some of the developed countries in Europe ${ }^{43}$, while our data set also covers (developing) countries in South America and Asia. This limits the extent to which the literature survey explains worldwide developments in (female) entrepreneurial activity. Some caution is needed interpreting the results of this study. Considering the limited number of observations (i.e., countries) in our data set and the selection of explanatory variables (in light of data availability), the present study should be seen as an exploratory study, guiding future studies in this area. Future research should try and include more countries in the analysis and investigating more explanatory factors ${ }^{44}$. More cultural and political factors should be included to rule out country differences in these areas. Moreover, future research should include a larger range of institutional factors, such as support for entrepreneurship, taxation and social security. Obviously, this study leaves room for investigating the nature and origin of female entrepreneurship within the context of particular countries, comparing them in terms of differences with respect to the factors that have been identified as 'predictors' of female entrepreneurship. Factors influencing female entrepreneurship in developing countries may be different from those in developed countries ${ }^{45}$.

Findings in the present study also indicate that there may be a considerable share of (particularly female) entrepreneurs active in the informal sector, especially in less developed countries. To be able to provide full understanding of the reasons why women become selfemployed, future research exploring female entrepreneurial motivation should take into account both formal and informal economic sectors. Moreover, we find that unemployment has a different effect on female than on male entrepreneurship. Hence, it may be interesting to study the mechanisms of the career choice of unemployed people. For instance, the effect of unemployment on the self-employment decision is likely to be dependent upon the reasons for unemployment, where a distinction can be made between voluntary unemployment (e.g., 
because of maternity leave, child and elderly care) or involuntary unemployment (e.g., because of company downsizing).

One of the most consistent influences on both female and male entrepreneurship throughout this study is the importance of family. For both women and men the importance of family has a positive impact on self-employment. Two factors probably play a role here. First, family can be supportive of the firm giving the entrepreneur a helping hand. Second, self-employment enables flexible working hours and working from the home. Accordingly, self-employment can be geared to family needs. It is interesting to see that importance of family for men also influences the entrepreneurial activity of women (in addition to that of men). Hence, if men become entrepreneurs, their wives probably also contribute as unpaid family workers. Our correlation analysis suggests that this does not work the other way around, i.e., if women become self-employed, their husbands are not more likely to become involved in their firms. This gives rise to question how far the (global) gender mainstreaming process has advanced. To what extent do women and men throughout the world have equal access to economic opportunities and are intra-household relations emancipatory?

A striking result of this study is the positive effect of life satisfaction on the number of female entrepreneurs, which is contrary to the 'social legitimation' perspective. Hence, life satisfaction may be an important policy issue for governments that aim to stimulate female entrepreneurship. Although life satisfaction is largely dependent upon factors that are difficult to influence, such as personal happiness and the economic climate, governments may be able to create higher levels of satisfaction among its female population by targeting problem areas and important issues for women, such as child care issues and gender mainstreaming. These issues may impact female entrepreneurship directly, but also indirectly through satisfaction. Though it may be a long shot for governments to influence female entrepreneurship through satisfaction, awareness of this relationship is important. 
Another promising line of research is the investigation of crosswise effects: the extent to which male-specific developments also impact female entrepreneurship and vice versa. In the present paper we investigated this issue using correlation analysis only. Follow-up research may also test for the existence of crosswise effects in regression analyses.

From a policy perspective it may be argued that before selecting and activating policy instruments, governments should have a clear idea what they want to accomplish: do they want to stimulate the number of female entrepreneurs or the female share in entrepreneurship (i.e., the diversity of entrepreneurship)? The analyses in this study point out that there may be different factors involved. Considering that diversity of entrepreneurship is important from an economic perspective - because of the extended and more diverse supply of goods and services consumers can choose from - it may be important for governments to focus on stimulating the share of women in entrepreneurship. To this end, government policy should aim at influencing those factors that have a relatively stronger impact on female than on male entrepreneurship. Also, more systematic data collection is of vital importance for governments to have a clear understanding of the role of female entrepreneurship in the economic process and the relationships between entrepreneurship and other factors. Knowledge of the number and share of female entrepreneurs in different countries fosters large-scale research in the area of female entrepreneurship both within and across countries. Past and contemporary research on female entrepreneurship has mainly focused upon small groups of female entrepreneurs (in qualitative research) within countries.

\section{Acknowledgement}

\footnotetext{
* The authors would like to thank Nancy Carter, Sander Wennekers and two anonymous referees for comments on an earlier version of the paper. Ingrid Verheul acknowledges financial support by the Fund Schiedam Vlaardingen e.o. and the Trust Fund Rotterdam. Early versions of the present paper have been read at the Babson Kauffman Entrepreneurship Research Conference at Babson College, Boston, June 6-8, 2003, at the RENT conference in Lodz, Poland, November 20-21, 2003, and at the First GEM Research Conference, Berlin, April 13, 2004.
} 


\section{References}

Anna, A.L., Chandler, G.N., Jansen, E. and N.P. Mero, 1999, Women business owners in traditional and non-traditional industries, Journal of Business Venturing 15, 279-303.

Audretsch, D.B., Carree, M.A., Van Stel, A.J. and A.R. Thurik, 2005, Does Self-Employment Reduce Unemployment?, Discussion Paper 07-2005 on Entrepreneurship, Growth and Public Policy, Jena, Germany: Max Planck Institute of Economics.

Baum, J.R., Olian, J.D., Erez, M., Schnell, E.R., Smith, K.G., Sims, H.P., Scully, J.S. and K.A. Smith, 1993, Nationality and work role interactions: a cultural contrast of Israeli and US entrepreneurs' versus managers’ needs, Journal of Business Venturing 8, 499-512.

Berger, A.N. and G.F. Udell, 1998, The economics of small business finance: the roles of private equity and debt markets in the financial growth cycle, Journal of Banking and Finance 22, 613-673.

Blanchflower, D.G., 2004, Self-employment: more may not be better, Swedish Economic Policy Review 11(2), 15-73.

Bleaney, M. and A. Nishiyama, 2002, Explaining Growth: A Contest Between Models, Journal of Economic Growth 7, 43-56.

Brayfield, A.H., Wells, R.V. and N.W. Strate, 1957, Interrelationships among measures of job satisfaction and general satisfaction, Journal of Applied Psychology 41, 201-205.

Breedveld, K., 2000, Verdienen en verdelen [Earn and distribute], in: Keuzenkamp, S. and E. Hooghiemstra (eds.), De Kunst van het Combineren [The Art of Combining Responsibilities], The Hague: Sociaal en Cultureel Planbureau, 29-48.

Bregger, J.E., 1996, Measuring self-employment in the United States, Monthly Labor Review 119 (1), 3-9.

Brunner, Hans-Peter, 1993, The development experience and government policies in SouthEast Asia with respect to small firms: Lessons for Eastern Europe?, in: Acs, Z.J. and D.B. Audretsch (eds), Small Firms and Entrepreneurship - An East-West Perspective, Cambridge: Cambridge University Press.

Brush, C.G., 1992, Research on women business owners: past trends, a new perspective and future directions, Entrepreneurship: Theory and Practice 16 (4), 5-30.

Busenitz, L.W., Gomez, C. and J.W. Spencer, 2000, Country institutional profiles: unlocking entrepreneurial phenomena, Academy of Management Journal 43 (5) 994-1003.

Buttner, E.H. and B. Rosen, 1989, Funding new business ventures: are decision makers biased against women entrepreneurs?, Journal of Business Venturing 4 (4), 249-261.

Carree, M.A., Van Stel, A.J., Thurik, A.R. and A.R.M. Wennekers, 2002, Economic development and business ownership: an analysis using data of 23 OECD countries in the period 1976-1996, Small Business Economics 19 (3), 271-290.

Carter, S., 2000, Gender and enterprise. In: Carter, S. and D. Jones-Evans (eds.), Enterprise and Small Business. Principles, Practice and Policy, Harlow: Prentice Hall / Pearson Education Limited, 166-181.

Carter, S. en T. Cannon, 1992, Women as Entrepreneurs, London: Academic Press.

Carter, N.M., Williams, M. and P.D. Reynolds, 1997, Discontinuance among new firms in retail: the influence of initial resources, strategy and gender, Journal of Business Venturing 12, 125-145.

Casson, M., 1995, Entrepreneurship and Business Culture; Studies in the Economics of Trust, vol.1, Cheltenham (U.K.): Edward Elgar Publishing.

Chaganti, R. and S. Parasuraman, 1996, A study of the impacts of gender on business performance and management patterns in small businesses, Entrepreneurship: Theory and Practice, Winter 1996, 73-75. 
Chittenden, F., Hall, G. and P. Hutchinson, 1996, Small firm growth, access to capital markets and financial structure: review of issues and an empirical investigation, Small Business Economics 8, 59-67.

Cooper, A.C. and W.C. Dunkelberg, 1987, Entrepreneurial research: old questions, new answers and methodological issues, American Journal of Small Business 1, 11-23.

Cressy, R., 2002, Introduction: funding gaps, The Economic Journal 112 (477), 1-16.

Cressy, R., 2005, Debt finance and entrepreneurship, in: Parker, S.C. (ed.), International Handbook of Entrepreneurship (volume III), Kluwer International Handbook Series on Entrepreneurship, forthcoming.

Davidsson, P., 1995, Culture, structure and regional levels of entrepreneurship, Entrepreneurship and Regional Development 7, 41-62.

Delmar, F., 2003, Women entrepreneurship: assessing data availability and future needs, paper for the Workshop on Improving Statistics on SMEs and Entrepreneurship, OECD, Paris, 17-19 September 2003.

Delmar, F. and P. Davidsson, 2000, Where do they come from? Prevalence and characteristics of nascent entrepreneurs, Entrepreneurship and Regional Development 12, 1-23.

EIM/ENSR, 1996, The European Observatory for SMEs: fourth annual report, Zoetermeer: EIM Business and Policy Research.

EIM/ENSR, 1997, The European Observatory for SMEs: fifth annual report, Zoetermeer: EIM Business and Policy Research.

Erutku, C. and Vallée, 1997, Business start-ups in today's Poland: who and how?, Entrepreneurship and Regional Development 9, 113-126.

Etzioni, A., 1987, Entrepreneurship, adaptation and legitimation: a macro-behavioral perspective, Journal of Economic Behaviour and Organization 8, 175-189.

Evans, D.S. and L.S. Leighton, 1989, The determinants of changes in US self-employment, 1968-1987, Small Business Economics 2, 319-330.

Fischer, E.M., Reuber, A.R. and L.S. Dyke, 1993, A theoretical overview and extension of research on sex, gender and entrepreneurship, Journal of Business Venturing 8, 151-168.

Grilo, I. and A.R. Thurik, 2005a, Latent and actual entrepreneurship in Europe and the US: some recent developments, International Entrepreneurship and Management Journal 1(4), forthcoming.

Grilo, I. and A.R. Thurik, 2005b, Entrepreneurial engagement levels in the European Union, International Journal of Entrepreneurship Education, forthcoming.

Gustafsson, S. and R. Jacobsson, 1985, Trends in female labor force participation in Sweden, Journal of Labor Economics 3 (1), S256-S274.

Henrekson, M. and D. Johansson, 1999, Institutional effects on the evolution of the size distribution of firms, Small Business Economics 12, 11-23.

Hisrich, R. and C.G. Brush, 1986, The Women Entrepreneur: Starting, Financing and managing a Successful New Business, Lexington, MA: Lexington Books.

Hofstede, G., 1980, Culture's Consequences: International Differences in Work-Related Values, Beverly Hills: Sage.

Hofstede, G., 2001, Culture's Consequences: Comparing Values, Behaviors, Institutions and Organizations Across Nations, $2^{\text {nd }}$ edition, Thousand Oaks: Sage.

Hofstede, G., Noorderhaven, N.G., Thurik, A.R., Wennekers, A.R.M., Uhlaner, L.M. and R.E. Wildeman, 2004, Culture's role in entrepreneurship: self-employment out of dissatisfaction, in: Ulijn, J. and T. Brown (eds), Innovation, Entrepreneurship and Culture: The Interaction between Technology, Progress and Economic Growth, Cheltenham (UK) and Brookfield (US): Edward Elgar, 162-203.

Hughes, A. and D.J. Storey, 1994, Finance and the Small Firm, London/New York: Routledge. 
ILO, 1984, World Labor Report vol. 1, Geneva, Switzerland: International Labor Organization.

Jacobsson, S., Oskarsson, C. and J. Philipson, 1996, Indicators of technological activities comparing educational, patent and R\&D statistics in the case of Sweden, Research Policy 25, 573-585.

Kalleberg, A. and K. Leicht, 1991, Gender and organizational performance: determinants of small business survival and success, Academy of Management Journal 34, 136-161.

Kovalainen, A., Arenius, P. and L. Galloway, 2002, Entrepreneurial activity of women in the global economy: analysis of data from 29 countries, paper presented at the Babson Kauffman Entrepreneurship Research Conference 2002, Boulder Colorado.

Kuznets, S., 1966, Modern Economic Growth: Rate, Structure and Spread, New Haven: Yale University Press.

Lin, Z., Picot, G. and J. Compton, 2000, The entry and exit dynamics of self-employment in Canada, Small Business Economics 15 (2), 105-125.

Loscocco, K.A. and J. Robinson, 1991, Barriers to women's small business success in the United States, Gender and Society 5 (4), 511-532.

Lucas, R.E., 1978, On the size distribution of firms, BELL Journal of Economics 9, 508-523.

McGrath, R.G. and I.C. MacMillan, 1992, More like each other than anyone else? Crosscultural study of entrepreneurial perceptions, Journal of Business Venturing 7 (5) 419-429.

McGrath, R.G., MacMillan, I.C. and S. Scheinberg, 1992, Elitists, risk-takers, and rugged individualists? An exploratory analysis of cultural differences between entrepreneurs and non-entrepreneurs, Journal of Business Venturing 7 (2), 115-136.

Mincer, J., 1985, Intercountry comparisons of labor force trends and of related developments: an overview, Journal of Labor Economics 3 (1), S1-S32.

Minniti, M., Arenius, P. and N. Langowitz, 2005, Global Entrepreneurship Monitor 2004 Report on Women and Entrepreneurship, Babson College: The Centre for Women's Leadership and London Business School.

Mueller, S.L. and A.S. Thomas, 2000, Culture and entrepreneurial potential: a nine country study of locus of control and innovativeness, Journal of Business Venturing 16, 51-75.

Mugler, J., 2000, The climate for entrepreneurship in European countries in transition, in: Sexton, D.L. and H. Landström (eds.), The Blackwell Handbook of Entrepreneurship, Oxford / Malden: Blackwell, pp. 150-175.

Noorderhaven, N.G., Thurik, A.R., Wennekers, A.R.M. and A.J. van Stel, 2004, The Role of Dissatisfaction and Per Capita Income in Explaining Self-Employment across 15 European Countries, Entrepreneurship Theory and Practice 28 (5) 447-466.

OECD, 1998, Fostering Entrepreneurship, the OECD jobs strategy, Paris: OECD.

OECD, 2001, OECD Employment Outlook: June 2001, Paris: OECD.

OECD, 2002, OECD Employment Outlook: July 2002, Paris: OECD.

Oppenheimer, V.K., 1970, The Female Labor Force in the United States (Population Monograph Series, No. 5), Berkeley, CA: Institute of International Studies, University of California Press.

Parker, S.C., 2004, The Economics of Self-Employment and Entrepreneurship, Cambridge: Cambridge University Press.

Reynolds, P.D., 1997, Who starts new firms? Preliminary explorations of firms-in-generation, Small Business Economics 9, 449-462.

Reynolds, P.D., M. Hay and S.M. Camp, 1999, Global Entrepreneurship Monitor: 1999 Executive Report, Babson College, London Business School and the Kauffman Center for entrepreneurial leadership.

Reynolds, P.D., Bygrave, W.D., Autio, E., Cox, L.W. and M. Hay, 2002, Global Entrepreneurship Monitor, 2002 Executive Report, Babson College, London Business School and Kauffman Foundation. 
Riding, A.L. and C.S. Swift, 1990, Women business owners and terms of credit: some empirical findings of the Canadian experience, Journal of Business Venturing 5 (5), 327340.

Roman, Z., 1990, Strengthening small and medium-sized enterprises in Eastern European economies, paper presented at the UNDP/UNIDO workshop, Trieste, Italy.

Ruminska-Zimny, E., 2002, Women's entrepreneurship and labour market trends in transition countries, in: Women's Entrepreneurship in Eastern Europe and CIS Countries, UNECE, Geneva: United Nations.

Schultz, T.P., 1990, Women's changing participation in the labor force: a world perspective, Economic Development and Cultural Change 38 (3), 457-488.

Schwartz, E.B., 1976, Entrepreneurship: a new female frontier, Journal of Contemporary Business, Winter, 47-76.

Shane, S., 1992, Why do some societies invent more than others? Journal of Business Venturing 7, 29-46.

Shane, S., 1993, Cultural influences on national rates of innovation, Journal of Business Venturing 8, 59-73.

Shane, S., Kolvereid, L. and P. Westhead, 1991, An exploratory examination of the reasons leading to new firm formation across country and gender, Journal of Business Venturing 6, 431-446.

Smallbone, D. and F. Welter, 2001, The distinctiveness of entrepreneurship in transition economies, Small Business Economics 16, 249-262.

Storey, D.J., 1991, The Birth of New Firms - Does Unemployment Matter? A Review of the Evidence, Small Business Economics 3, 167-178.

Storey, D.J., 1999, Six steps to heaven: evaluating the impact of public policies to support small business in developed economies, in: D.L. Sexton and H. Landström (eds.), Handbook of Entrepreneurship, Oxford: Blackwell, 176-194.

Tambunan, T., 1992, Economic development and small scale enterprises in Indonesia, Entrepreneurship and Regional Development 4, 85-98.

Tambunan, T., 1994, Rural small-scale industries in a developing region: sign of poverty or progress? A case study in Ciomas Subdistrict, West-Java Province, Indonesia, Entrepreneurship and Regional Development 6, 1-13.

Uhlaner, L.M., Thurik, A.R. and J. Hutjes, 2002, Post-materialism: a cultural factor influencing entrepreneurial activity across nations, ERIM Report ERS-2002-62-STR, Rotterdam: Erasmus Research Institute for Management.

UNECE (United Nations Economic Commission for Europe), 2002, Women's Entrepreneurship in Eastern Europe and CIS Countries (Entrepreneurship and SMEs series), Geneva: United Nations.

Unger, R.K. and M. Crawford, 1992, Women and Gender: A Feminist Psychology, New York: McGraw-Hill.

Van der Kuip, I and I. Verheul, 2004, Early development of entrepreneurial qualities: the role of initial education, Journal of Entrepreneurship Education 2 (2), 2003/2004, 203-226.

Verheul, I., 2003, Commitment or control? Human resource management in female- and male-led businesses, Strategic Study B200206, Zoetermeer: EIM Business and Policy Research.

Verheul, I., 2005, Is there a (fe)male approach? Understanding gender differences in entrepreneurship, ERIM PhD. Series Research in Management, Erasmus Research Institute of Management, Erasmus University Rotterdam.

Verheul, I. and A.R. Thurik, 2001, Start-up capital: does gender matter? Small Business Economics 16, 329-345.

Verheul, I., Wennekers, A.R.M., Audretsch, D.B. and A.R. Thurik, 2002, An eclectic theory of entrepreneurship, in: D.B. Audretsch, A.R. Thurik, I. Verheul and A.R.M. Wennekers 
(eds.), Entrepreneurship: Determinants and Policy in a European-US Comparison, Boston/Dordrecht: Kluwer Academic Publishers.

Vroom, V.H., 1982, Work and Motivation, Malabar, Florida: Robert E. Krieger Publishing Company.

Ward, K.B. and F.C. Pampel, 1985, Structural determinants of female labor force participation in developed nations, 1955-1978, Social Science Quarterly 66, 654-667.

Wennekers, A.R.M., Uhlaner, L.M. and A.R. Thurik, 2002, Entrepreneurship and its conditions: a macro perspective, International Journal of Entrepreneurship Education 1 (1), 25-64.

Wennekers, A.R.M., Van Stel, A.J., Thurik, A.R. and P.D. Reynolds, 2005, Nascent Entrepreneurship and the Level of Economic Development, Small Business Economics 24 (3), 293-309.

World Bank, 2005, Doing Business in 2005, Removing Obstacles to Growth, Washington: World Bank, co-published with the International Finance Corporation and Oxford University Press. 


\section{Tables and Figures}

Table 1: Female, male, and total entrepreneurial activity rates for 29 GEM countries (2002) ${ }^{\text {a }}$

\begin{tabular}{|l|c|c|c|l|c|c|c|}
\hline Country & Female & Male & Total & Country & Female & Male & Total \\
\hline India & 14.1 & 21.4 & 17.9 & Denmark & 4.2 & 8.8 & 6.5 \\
\hline Argentina & 11.5 & 16.8 & 14.2 & Italy & 4.1 & 7.8 & 5.9 \\
\hline Brazil & 11.1 & 16.0 & 13.5 & Poland & 3.6 & 5.3 & 4.4 \\
\hline Mexico & 10.3 & 14.6 & 12.4 & Netherlands & 3.5 & 5.7 & 4.6 \\
\hline Chile & 9.5 & 21.9 & 15.7 & Finland & 3.5 & 5.6 & 4.6 \\
\hline Korea & 8.6 & 20.3 & 14.5 & Germany & 3.4 & 6.9 & 5.2 \\
\hline United States & 8.1 & 12.9 & 10.5 & United Kingdom & 3.3 & 7.4 & 5.4 \\
\hline Iceland & 7.9 & 14.8 & 11.3 & Slovenia & 2.9 & 6.4 & 4.6 \\
\hline Canada & 6.0 & 11.7 & 8.8 & Sweden & 2.6 & 5.4 & 4.0 \\
\hline South Africa & 5.8 & 7.3 & 6.5 & Spain & 2.6 & 6.6 & 4.6 \\
\hline Australia & 5.6 & 11.7 & 8.7 & France & 2.1 & 4.3 & 3.2 \\
\hline Ireland & 5.5 & 12.4 & 9.1 & Russia & 1.6 & 3.5 & 2.5 \\
\hline Switzerland & 4.8 & 9.4 & 7.1 & Belgium & 1.5 & 4.4 & 3.0 \\
\hline Norway & 4.7 & 12.6 & 8.7 & Japan & 0.6 & 3.0 & 1.8 \\
\hline Hungary & 4.4 & 8.9 & 6.6 & & & & \\
\hline
\end{tabular}

${ }^{a}$ Female, male, and total entrepreneurial activity rates refer to the share of adults in the female, male and total population of 18 to 64 years old who are either actively involved in starting a new business or in managing a business less than 42 months old (Reynolds et al., 2002, p. 5).

Table 2: Female share in total entrepreneurial activity for 29 GEM countries (2002) ${ }^{\mathrm{a}}$

\begin{tabular}{|l|c|l|c|}
\hline Country & $\begin{array}{l}\text { Female share in } \\
\text { entrepreneurship }\end{array}$ & Country & $\begin{array}{l}\text { Female share in } \\
\text { entrepreneurship }\end{array}$ \\
\hline South Africa & 44.3 & France & 32.6 \\
\hline Mexico & 41.5 & Sweden & 32.5 \\
\hline Brazil & 41.2 & Denmark & 32.5 \\
\hline Poland & 40.8 & Australia & 32.1 \\
\hline Argentina & 40.8 & Russia & 31.6 \\
\hline India & 39.4 & Slovenia & 30.9 \\
\hline United States & 38.8 & United Kingdom & 30.4 \\
\hline Finland & 38.7 & Chile & 30.3 \\
\hline Netherlands & 38.3 & Ireland & 30.2 \\
\hline Iceland & 34.8 & Korea & 29.5 \\
\hline Italy & 34.3 & Spain & 28.1 \\
\hline Switzerland & 33.8 & Norway & 26.9 \\
\hline Canada & 33.8 & Belgium & 25.5 \\
\hline Hungary & 33.3 & Japan & 17.5 \\
\hline Germany & 32.7 & & \\
\hline
\end{tabular}

${ }^{a}$ The female share in entrepreneurship is calculated from Table 1 as the female entrepreneurial activity rate divided by twice the total entrepreneurial activity rate. 
Table 3: Description of variables

\begin{tabular}{|c|c|}
\hline Dependent Variables & Variable Description \\
\hline total entrepreneurial activity & $\begin{array}{l}\text { Share of people in age group of } 18 \text { to } 64 \text { years who are actively engaged in } \\
\text { the start-up process or managing a business less than } 42 \text { months old in } 2002 \\
\text { (in \%). Source: Global Entrepreneurship Monitor }\end{array}$ \\
\hline female entrepreneurial activity & $\begin{array}{l}\text { Share of women in age group of } 18 \text { to } 64 \text { years who are actively engaged in } \\
\text { the start-up process or managing a business less than } 42 \text { months old in } 2002 \\
\text { (in \%). Source: Global Entrepreneurship Monitor }\end{array}$ \\
\hline male entrepreneurial activity & $\begin{array}{l}\text { Share of men in age group of } 18 \text { to } 64 \text { years who are actively engaged in the } \\
\text { start-up process or managing a business less than } 42 \text { months old in } 2002 \text { (in } \\
\text { \%). Source: Global Entrepreneurship Monitor. }\end{array}$ \\
\hline $\begin{array}{l}\text { female share in total } \\
\text { entrepreneurial activity }\end{array}$ & $\begin{array}{l}\text { Share of female entrepreneurs in total number of entrepreneurs in } 2002 \text {, } \\
\text { derived from female and male entrepreneurial activity rates described above } \\
\text { (in \%). Source: Global Entrepreneurship Monitor }\end{array}$ \\
\hline Independent Variables & Variable description \\
\hline R\&D expenditure & $\begin{array}{l}\text { Total R\&D expenditure per capita in } 2000 \text { (per } 1000 \text { US\$), Source: World } \\
\text { Competitiveness Yearbook. }\end{array}$ \\
\hline Per capita income (squared) & $\begin{array}{l}\text { Gross national income per capita in } 2001 \text { in purchasing power parities per } \\
1000 \text { US Dollars, 2002. Source: World Development Indicators (World } \\
\text { Bank) }\end{array}$ \\
\hline Unemployment & $\begin{array}{l}\text { Unemployment rate for 2001, Source: World Competitiveness Yearbook } \\
2002 .\end{array}$ \\
\hline Service employment & $\begin{array}{l}\text { Employment in the service sector as percentage of total employment in 2000, } \\
\text { Source: World Competitiveness Yearbook } 2001 .\end{array}$ \\
\hline Informal sector & $\begin{array}{l}\text { Expert question: "What percentage of businesses in your country would you } \\
\text { guess are unofficial or not registered?" (1=less than 5\%; 2=6-10\%; 3=11- } \\
\text { 20\%; 4=21-30\%; ....; 8=61-70\%; 9=more than 70\%). Source: Global } \\
\text { Competitiveness Report 2001-2002. }\end{array}$ \\
\hline Female labor share & $\begin{array}{l}\text { Female employment as a percentage of the total labor force in 2001, Source: } \\
\text { World Competitiveness Yearbook } 2002 .\end{array}$ \\
\hline Former communist country & $\begin{array}{l}\text { Dummy variable for former communist country. The variable has value ' } 1 \text { ' } \\
\text { for Russia, Hungary, Poland, and Slovenia, and value ' } 0 \text { ' for all other } \\
\text { countries. }\end{array}$ \\
\hline Importance family & $\begin{array}{l}\text { Average country score to following question: "How important is family in } \\
\text { your life?” (1=very important; 2=rather important; 3=not very important; } \\
\text { 4=not at all important). Source: World Values Surveys and European Values } \\
\text { Surveys, cumulative data: } 1981-1984 ; 1990-1993 ; 1995-1997 . \text { Note that this } \\
\text { variable has descending values. In the present paper we have used this } \\
\text { variable with a reverse ordering, i.e., ascending values, to enable } \\
\text { straightforward interpretation of the empirical results. }\end{array}$ \\
\hline Entry regulation & $\begin{array}{l}\text { Number of days required to start up a new business, Source: Global } \\
\text { Competitiveness Report 2001-2002 }\end{array}$ \\
\hline Informal venture capital & $\begin{array}{l}\text { Percentage of respondents that has indicated to have financially supported a } \\
\text { firm (as a 'business angel') in the last } 3 \text { years, Source: Global } \\
\text { Entrepreneurship Monitor } 2002\end{array}$ \\
\hline Maternity leave coverage $^{\mathrm{a}}$ & $\begin{array}{l}\text { \{Maternity leave benefits (share of wages paid covered)\}* (i.e., multiplied } \\
\text { by) }\{\text { time during which maternity benefits are paid (in weeks)\} / (i.e., divided } \\
\text { by) } 100 . \text { Source(s): World Development Indicators (World Bank) \& Social } \\
\text { Security Worldwide } 2003 \text {. }\end{array}$ \\
\hline Life satisfaction & $\begin{array}{l}\text { Average country score to the question: “All things considered, how satisfied } \\
\text { are you with your life as a whole these days?”, using a 10-point Likert scale } \\
\text { from '1' dissatisfied, to '10' satisfied. Source: World Values Surveys and } \\
\text { European Values Surveys, cumulative data: 1981-1984; 1990-1993; 1995- } \\
\text { 1997. }\end{array}$ \\
\hline
\end{tabular}


Table 4: Pearson correlation between dependent and independent variables $(N=29)$

\begin{tabular}{|c|c|c|c|c|c|c|c|c|c|c|c|c|c|c|c|c|c|}
\hline & 1 & 2 & 3 & 4 & 5 & 6 & 7 & 8 & 9 & 10 & 11 & 12 & 13 & 14 & 15 & 16 & 17 \\
\hline 1. total entrepreneurial activity & 1 & & & & & & & & & & & & & & & & \\
\hline $\begin{array}{l}\text { 2. female entrepreneurial } \\
\text { activity }\end{array}$ & $0.97^{* *}$ & 1 & & & & & & & & & & & & & & & \\
\hline 3. male entrepreneurial activity & $0.99^{\star \star}$ & $0.92^{\star \star}$ & 1 & & & & & & & & & & & & & & \\
\hline $\begin{array}{l}\text { 4. female share in total } \\
\text { entrepreneurial activity }\end{array}$ & $0.37^{*}$ & $0.55^{\star \star}$ & 0.26 & 1 & & & & & & & & & & & & & \\
\hline 5. R\&D investments & -0.36 & $-0.39 *$ & -0.33 & $-0.38^{*}$ & 1 & & & & & & & & & & & & \\
\hline 6. per capita income & $-0.40^{\star}$ & $-0.48^{\star \star}$ & -0.34 & $-0.45^{*}$ & $0.81^{* \star}$ & 1 & & & & & & & & & & & \\
\hline 7. per capita income squared & -0.31 & $-0.38^{\star}$ & -0.27 & $-0.39^{\star}$ & $0.83^{\star \star}$ & $0.98^{\star \star}$ & 1 & & & & & & & & & & \\
\hline 8. unemployment & 0.01 & 0.12 & -0.06 & $0.45^{\star}$ & $-0.51^{\star *}$ & $-0.54^{\star *}$ & $-0.55^{\star \star}$ & 1 & & & & & & & & & \\
\hline 9. service sector employment & -0.29 & -0.33 & -0.25 & -0.15 & $0.50 \star \star$ & $0.69^{\star \star}$ & $0.64^{\star \star}$ & -0.13 & 1 & & & & & & & & \\
\hline 10. informal sector & 0.33 & $0.48^{\star \star}$ & 0.24 & $0.54^{\star \star}$ & $-0.67^{\star \star}$ & $-0.81^{\star *}$ & $-0.77^{\star \star}$ & $0.45^{\star}$ & $-0.52^{\star \star}$ & 1 & & & & & & & \\
\hline 11. female labor share & $-0.60^{\star \star}$ & $-0.59 * \star$ & $-0.58^{\star \star}$ & -0.07 & $0.40^{\star}$ & $0.48^{\star \star}$ & $0.44^{*}$ & -0.14 & $0.40^{\star}$ & -0.33 & 1 & & & & & & \\
\hline 12. former communist country & -0.31 & -0.28 & -0.31 & 0.03 & $-0.38^{\star}$ & $-0.39^{*}$ & $-0.42^{\star}$ & 0.13 & $-0.45^{\star}$ & 0.23 & 0.25 & 1 & & & & & \\
\hline 13. importance family & $0.44^{*}$ & $0.40^{*}$ & $0.45^{\star}$ & 0.17 & -0.04 & -0.01 & 0.04 & 0.17 & 0.17 & -0.01 & 0.02 & -0.14 & 1 & & & & \\
\hline 14. entry regulation & 0.24 & 0.30 & 0.20 & 0.14 & $-0.48^{\star \star}$ & $-0.48^{\star *}$ & $-0.46^{\star}$ & 0.25 & $-0.52^{\star *}$ & $0.51^{\star \star}$ & $-0.56^{\star \star}$ & 0.01 & 0.14 & 1 & & & \\
\hline 15. informal venture capital & $0.46^{*}$ & $0.38^{*}$ & $0.50^{* \star}$ & 0.10 & 0.17 & 0.21 & 0.26 & -0.34 & 0.08 & -0.10 & 0.12 & -0.30 & -0.13 & -0.13 & 1 & & \\
\hline 16. maternity leave coverage & -0.09 & -0.10 & -0.08 & -0.05 & 0.09 & 0.06 & 0.04 & -0.19 & 0.01 & -0.03 & 0.30 & 0.18 & 0.02 & -0.11 & 0.10 & 1 & \\
\hline 17. life satisfaction & 0.07 & 0.05 & 0.08 & 0.01 & $0.56^{\star \star}$ & $0.64^{\star \star}$ & $0.66^{\star *}$ & $-0.50^{\star \star}$ & $0.57^{\star \star}$ & $-0.49^{\star \star}$ & 0.13 & $-0.56^{* \star}$ & 0.11 & -0.25 & 0.35 & 0.22 & 1 \\
\hline MEAN & 7.79 & 5.43 & 10.13 & 33.69 & 0.40 & 20.80 & 510.30 & 7.90 & 64.27 & 2.38 & 42.95 & $0.14^{a}$ & -1.16 & 39.90 & 0.03 & 19.79 & 7.17 \\
\hline STANDARD DEVIATION & 4.32 & 3.38 & 5.43 & 5.72 & 0.37 & 8.96 & 339.60 & 5.85 & 11.58 & 1.04 & 4.39 & 0.35 & 0.06 & 26.88 & 0.02 & 14.68 & 0.79 \\
\hline
\end{tabular}

Note: * Correlation is significant at the 0.05 -level (2-tailed); ** Correlation is significant at the 0.01-level (2-tailed). 
Table 5: Regression analysis explaining entrepreneurial activity (including 13 variables)

\begin{tabular}{|c|c|c|c|c|c|c|}
\hline & \multicolumn{6}{|c|}{ Entrepreneurial activity } \\
\hline & \multicolumn{2}{|c|}{ Total } & \multicolumn{2}{|c|}{ Female } & \multicolumn{2}{|c|}{ Male } \\
\hline & $B$-value & $t$-value & $B$-value & $t$-value & $B$-value & $t$-value \\
\hline constant & 58.09 & 5.35 & 33.61 & 3.58 & 81.34 & 6.09 \\
\hline R\&D investments & -3.47 & -1.81 & -1.81 & -1.09 & -5.00 & -2.12 \\
\hline per capita income & -0.65 & -1.94 & -0.57 & -1.96 & -0.76 & -1.85 \\
\hline per capita income squared & 0.012 & 1.62 & 0.012 & 1.76 & 0.014 & 1.44 \\
\hline unemployment & -0.15 & -1.58 & -0.04 & -0.53 & -0.26 & -2.23 \\
\hline service sector employment & -0.009 & -0.14 & -0.02 & -0.39 & 0.014 & 0.18 \\
\hline informal sector & -0.25 & -0.36 & 0.54 & 0.88 & -1.06 & -1.21 \\
\hline female labor share & -0.37 & -2.57 & -0.25 & -1.95 & -0.49 & -2.73 \\
\hline former communist country & -2.72 & -1.54 & -1.78 & -1.17 & -3.55 & -1.64 \\
\hline importance family & 23.86 & 3.41 & 15.52 & 2.57 & 31.96 & 3.72 \\
\hline entry regulation & -0.021 & -1.05 & -0.017 & -0.96 & -0.023 & -0.93 \\
\hline informal venture capital & 95.24 & 3.62 & 57.95 & 2.55 & 133.43 & 4.13 \\
\hline maternity leave coverage & 0.002 & 0.08 & -0.006 & -0.23 & 0.01 & 0.28 \\
\hline life satisfaction & 0.40 & 0.50 & 0.95 & 1.38 & -0.16 & -0.16 \\
\hline$R$-square & & & & & & \\
\hline Adjusted $R$-square & & & & & & \\
\hline$N$ & & & & & & \\
\hline Degrees of freedom & & & & & & \\
\hline
\end{tabular}

Note: $t$-values in bold refer to effects with a significance level of 0.05 and a sign in accordance with the prediction in Hypotheses 1 to 12 (one-tailed test).

Table 6: Results of general-to-specific modeling procedure

\begin{tabular}{|c|c|c|c|c|c|c|}
\hline & \multicolumn{6}{|c|}{ Entrepreneurial activity } \\
\hline & \multicolumn{2}{|c|}{ Total } & \multicolumn{2}{|c|}{ Female } & \multicolumn{2}{|c|}{ Male } \\
\hline & $B$-value & $t$-value & $B$-value & $t$-value & $B$-value & $t$-value \\
\hline constant & 61.44 & 7.52 & 34.32 & 4.35 & 79.68 & 7.82 \\
\hline $\mathrm{R} \& \mathrm{D}$ investments & & & & . & -4.54 & -2.13 \\
\hline per capita income & -0.422 & -1.84 & -0.63 & -3.41 & -0.73 & -2.30 \\
\hline per capita income squared & 0.008 & 1.35 & 0.012 & 2.40 & 0.012 & 1.58 \\
\hline unemployment & 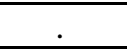 &. &. &. & -0.27 & -2.76 \\
\hline service sector employment & . & . & . & . &. &. \\
\hline informal sector & & . & . & . & -1.28 & -1.73 \\
\hline female labor share & -0.516 & -5.53 & -0.29 & -3.80 & -0.41 & -2.72 \\
\hline former communist country & & & & & -3.62 & -2.00 \\
\hline importance family & 26.35 & 4.17 & 16.27 & 3.21 & 34.07 & 4.48 \\
\hline entry regulation & & 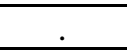 & &. &. &. \\
\hline informal venture capital & 129.2 & 5.67 & 72.30 & 3.84 & 133.41 & 4.51 \\
\hline maternity leave coverage & &. & & &. &. \\
\hline life satisfaction & & $\dot{.}$ & 1.08 & 2.13 & . & . \\
\hline$R$-square & & & & & & \\
\hline Adjusted $R$-square & & & & & & \\
\hline$N$ & & & & & & \\
\hline Degrees of freedom & & & & & & \\
\hline
\end{tabular}

Note: $t$-values in bold refer to effects with a significance level of 0.05 and a sign in accordance with the prediction in Hypotheses 1 to 12 (one-tailed test). 
Table 7: Regression analysis explaining female share in total number of entrepreneurs

\begin{tabular}{|l|c|c|}
\hline & $B$-value & $t$-value \\
\hline constant & -15.16 & -0.62 \\
\hline R\&D investments & -2.36 & -0.54 \\
\hline per capita income & -1.06 & -1.63 \\
\hline per capita income squared & 0.02 & 1.38 \\
\hline unemployment & 0.43 & 2.11 \\
\hline informal sector & 1.50 & 0.99 \\
\hline female labor share & 0.34 & 1.11 \\
\hline former communist country & 0.85 & 0.22 \\
\hline importance family & 5.01 & 0.32 \\
\hline informal venture capital & 29.67 & 0.49 \\
\hline life satisfaction & 4.53 & 2.82 \\
\hline & \multicolumn{2}{|c|}{0.635} \\
\hline$R$-square & \multicolumn{2}{|c|}{0.432} \\
\hline Adjusted $R$-square & \multicolumn{2}{|c|}{18} \\
\hline$N$ & 29 \\
\hline Degrees of freedom & in \\
\hline
\end{tabular}

Note: none of the variables have a significant effect that is in correspondence with the gender hypotheses 1a to 12a. Unemployment and life satisfaction appear to have an effect although the sign does not correspond with the hypotheses.

Table 8: Effects of one standard deviation change on TEA \& female entrepreneurship share

\begin{tabular}{|l|c|c|c|}
\hline & $\begin{array}{c}\text { TEA female } \\
\text { (\% of female adults) }\end{array}$ & $\begin{array}{c}\text { TEA male } \\
\text { (\% of male adults) }\end{array}$ & $\begin{array}{c}\text { Female share in TEA } \\
\text { (\% of total number } \\
\text { entrepreneurs) }\end{array}$ \\
\hline R\&D investments &. & -1.68 & -0.87 \\
\hline per capita income & -1.21 & -1.41 & 2.20 \\
\hline unemployment &. & -1.58 & 2.51 \\
\hline informal sector & - & -1.33 & 1.56 \\
\hline female labor share & -1.27 & -1.80 & 1.50 \\
\hline former communist country &. & -1.27 & 0.30 \\
\hline importance family & 0.98 & 2.04 & 0.30 \\
\hline informal venture capital & 1.45 & 2.67 & 0.59 \\
\hline life satisfaction & 0.85 &. & 3.58 \\
\hline
\end{tabular}

Note: the effects are computed on the basis of the estimation results from Table 6 and Table 7 . For per capita income the combined effect of the linear and the squared term is given for a per capita income change of 2,000 US\$.

Table 9: Pearson correlation between gender-specific variables and TEA (female/male)

\begin{tabular}{|c|c|c|c|c|c|c|c|c|c|c|}
\hline & 1 & 2 & 3 & 4 & 5 & 6 & 7 & 8 & 9 & 10 \\
\hline 1. female unemployment rate & 1 & & & & & & & & & \\
\hline 2. male unemployment rate & $0.94 * *$ & 1 & & & & & & & & \\
\hline 3. female service employment & -0.34 & -0.36 & 1 & & & & & & & \\
\hline 4. male service employment & 0.13 & 0.18 & $0.54 * *$ & 1 & & & & & & \\
\hline 5. importance family for women & 0.13 & 0.16 & 0.22 & 0.23 & 1 & & & & & \\
\hline 6. importance family for men & 0.18 & 0.22 & -0.06 & 0.16 & $-0.86^{* *}$ & 1 & & & & \\
\hline 7. life satisfaction for women & $-0.50 * *$ & $-0.54 * *$ & $0.69 * *$ & 0.22 & 0.20 & -0.01 & 1 & & & \\
\hline 8. life satisfaction for men & $-0.46 *$ & $-0.53 * *$ & $0.70^{* *}$ & 0.20 & 0.24 & 0.04 & $0.98^{* *}$ & 1 & & \\
\hline 9. TEA female & 0.07 & 0.13 & -0.25 & 0.06 & 0.28 & $0.51 * *$ & 0.03 & 0.05 & 1 & \\
\hline 10. TEA male & -0.12 & -0.05 & -0.12 & 0.04 & 0.34 & $0.54 * *$ & 0.07 & 0.10 & $0.92 * *$ & 1 \\
\hline MEAN & 8.23 & 7.16 & 76.88 & 56.30 & -1.13 & -1.19 & 7.16 & 7.15 & 5.43 & 10.13 \\
\hline STANDARD DEVIATION & 6.29 & 5.15 & 8.99 & 7.12 & 0.06 & 0.07 & 0.83 & 0.77 & 3.38 & 5.43 \\
\hline
\end{tabular}

Note: * Correlation is significant at the 0.05-level (2-tailed); ** Correlation is significant at the 0.01-level (2-tailed). 
Table 10a: Regression analysis explaining TEA female (including female-specific variables)

\begin{tabular}{|c|c|c|c|c|}
\hline & \multicolumn{2}{|c|}{$\begin{array}{c}\text { TEA female } \\
\text { (general variables only, } \\
\text { see Table 5) }\end{array}$} & \multicolumn{2}{|c|}{$\begin{array}{c}\text { TEA female } \\
\text { (including female- } \\
\text { specific variables) }\end{array}$} \\
\hline & $B$-value & $t$-value & $B$-value & $t$-value \\
\hline constant & 33.61 & 3.58 & 39.73 & 3.96 \\
\hline$R \& D$ investments & -1.81 & -1.09 & -2.46 & -1.45 \\
\hline per capita income & -0.57 & -1.96 & -0.79 & -3.25 \\
\hline per capita income squared & 0.012 & 1.76 & 0.017 & 2.69 \\
\hline (female) unemployment & -0.04 & -0.53 & -0.08 & -1.12 \\
\hline (female) service sector employment & -0.02 & -0.39 & -0.08 & -1.14 \\
\hline informal sector & 0.54 & 0.88 & 0.19 & 0.32 \\
\hline female labor share & -0.25 & -1.95 & -0.18 & -1.41 \\
\hline former communist country & -1.78 & -1.17 & -3.22 & -1.84 \\
\hline importance family (for women) & 15.52 & 2.57 & 15.76 & 2.69 \\
\hline entry regulation & -0.017 & -0.96 & -0.018 & -1.13 \\
\hline informal venture capital & 57.95 & 2.55 & 42.63 & 1.71 \\
\hline maternity leave coverage & -0.006 & -0.23 & -0.002 & -0.10 \\
\hline life satisfaction (for women) & 0.95 & 1.38 & 0.94 & 1.56 \\
\hline$R$-square & \multicolumn{2}{|c|}{0.879} & \multicolumn{2}{|c|}{0.893} \\
\hline Adjusted $R$-square & \multicolumn{2}{|c|}{0.775} & \multicolumn{2}{|c|}{0.800} \\
\hline $\mathrm{N}$ & \multicolumn{2}{|c|}{29} & \multicolumn{2}{|c|}{29} \\
\hline Degrees of freedom & \multicolumn{2}{|c|}{15} & \multicolumn{2}{|c|}{15} \\
\hline
\end{tabular}

Note: variables for which gender-specific information is used are indicated in bold. Moreover, $t$-values in bold refer to effects with a significance level of 0.05 and a sign in accordance with the prediction in Hypotheses 1 to 12 (one-tailed test).

Table 10b: Regression analysis explaining TEA male (including male-specific variables)

\begin{tabular}{|c|c|c|c|c|}
\hline & \multicolumn{2}{|c|}{$\begin{array}{c}\text { TEA male, } \\
\text { (general variables only, } \\
\text { see Table 5) }\end{array}$} & \multicolumn{2}{|c|}{$\begin{array}{c}\text { TEA male } \\
\text { including male-specific } \\
\text { variables }\end{array}$} \\
\hline & $B$-value & $t$-value & $B$-value & $t$-value \\
\hline constant & 81.34 & 6.09 & 66.37 & 3.96 \\
\hline R\&D investments & -5.00 & -2.12 & -5.04 & -1.97 \\
\hline per capita income & -0.76 & -1.85 & -0.73 & -1.91 \\
\hline per capita income squared & 0.014 & 1.44 & 0.013 & 1.37 \\
\hline (male) unemployment & -0.26 & -2.23 & -0.24 & -1.57 \\
\hline (male) service sector employment & 0.014 & 0.18 & 0.08 & 0.76 \\
\hline informal sector & -1.06 & -1.21 & -1.14 & -1.23 \\
\hline female labor share & -0.49 & -2.73 & -0.51 & -2.57 \\
\hline former communist country & -3.55 & -1.64 & -1.71 & -0.64 \\
\hline importance family (for men) & 31.96 & 3.72 & 25.59 & 3.11 \\
\hline entry regulation & -0.023 & -0.93 & -0.03 & -1.26 \\
\hline informal venture capital & 133.43 & 4.13 & 134.14 & 3.69 \\
\hline maternity leave coverage & 0.01 & 0.28 & 0.013 & 0.32 \\
\hline life satisfaction (for men) & -0.16 & -0.16 & 0.51 & 0.47 \\
\hline$R$-square & \multicolumn{2}{|c|}{0.905} & \multicolumn{2}{|c|}{0.886} \\
\hline Adjusted $R$-square & \multicolumn{2}{|c|}{0.823} & \multicolumn{2}{|c|}{0.787} \\
\hline $\mathrm{N}$ & \multicolumn{2}{|c|}{29} & \multicolumn{2}{|c|}{29} \\
\hline Degrees of freedom & \multicolumn{2}{|c|}{15} & \multicolumn{2}{|c|}{15} \\
\hline
\end{tabular}

Note: variables for which gender-specific information is used are indicated in bold. Moreover, $t$-values in bold refer to effects with a significance level of 0.05 and a sign in accordance with the prediction in Hypotheses 1 to 12 (one-tailed test). 


\section{Notes}

${ }^{1}$ See also Grilo and Thurik (2005a) for data of European member states.

${ }^{2}$ In 2002, there were 37 countries participating in GEM. For eight of these countries there was no information available for several of the explanatory variables that we use in this study. Therefore, the analysis in the current paper is restricted to 29 countries.

3 Indeed, for the 29 countries the Spearman rank correlation coefficient between the female and total entrepreneurial activity rate is 0.96 , which is significant at 0.01 -level.

${ }^{4}$ Although the Spearman rank correlation coefficient between the female entrepreneurial activity rate and the female share in entrepreneurship is significant, its value is only 0.53 , confirming that the two concepts are indeed different.

${ }^{5}$ A factor that has a positive impact on the absolute number of female entrepreneurs may at the same time have a negative impact on the female share in total entrepreneurship if its influence on the number of male entrepreneurs is relatively larger than that on the number of female entrepreneurs.

${ }^{6}$ We use 2002 as in this year the number of countries participating in GEM was higher than in the more recent years 2003 and 2004.

${ }^{7}$ See Verheul (2005), Blanchflower (2004) and Parker (2004) for surveys.

${ }^{8}$ In this paper technological development is operationalized as R\&D investments per capita.

${ }^{9}$ This implies that we expect a negative sign for the linear income variable and a positive sign for the squared income variable.

${ }^{10}$ Here it is proposed that there is no differential effect of income level on female and male entrepreneurship.

${ }^{11}$ Note that this is a reversed causality effect as it refers to unemployment as an effect of entrepreneurship and not as a cause of entrepreneurship. Because for this study we do not have time series data at our disposal, we are not able to test for reversed causality effects in our empirical analysis.

${ }^{12}$ Kovalainen et al. (2002) find a negative association between female unemployment and business start-ups by women.

${ }^{13}$ On the other hand, as women already occupy more than half of the employment in services, and men increasingly enter service jobs, the differential effect of growth in the number of service jobs on female and male entrepreneurship may be diminishing.

${ }^{14}$ As, in principle, GEM measures entrepreneurial activity in the formal sector, it may be argued that the size of the informal sector negatively impacts entrepreneurial activity in the formal sector.

${ }^{15}$ In the present paper we use the share of women in the labor force as an indicator of female labor force participation.

${ }^{16}$ Note that the entrepreneurial activity rate of GEM is scaled on population and not on labor force (or total employment).

${ }^{17}$ Grilo and Thurik (2005b) report on the differences of the entrepreneurial engagement levels between old and new member countries of the European Union.

${ }^{18}$ See also OECD (2001) and Breedveld (2000).

${ }^{19}$ For a discussion of these other demographic factors, we refer to Verheul (2005). It should be noted here that relatively few studies have been able to systematically link demographic factors to business start-ups at the macro-level (Delmar and Davidsson, 2000).

20 The possible loss of entitlements to social security upon becoming self-employed may constrain entrepreneurial activity (Henrekson and Johansson, 1999).

${ }^{21}$ Entrepreneurial aspects may include business qualities (e.g., management, financing, marketing knowledge) as well as more inherent entrepreneurial qualities (e.g., creativity, independence, perseverance). The latter qualities should be introduced and developed in an early phase of education (Van der Kuip and Verheul, 2004).

${ }^{22}$ We choose to formulate a hypothesis on entry regulation as this is likely to have an important impact on startup and new venture activity (as measured by GEM).

${ }^{23}$ Other studies do not find significant gender differences (Buttner and Rosen, 1989; Riding and Swift, 1990).

${ }^{24}$ We focus on informal venture capital instead of formal venture capital as the bulk of the entrepreneurs measured by GEM run small businesses. Formal venture capital is often acquired by larger businesses.

${ }^{25}$ Kovalainen et al. (2002) also find a negative relationship between the statutory support payment scheme as a percentage of wages and the new business rate of women.

${ }^{26}$ Several studies have focused upon explaining entrepreneurship from a cultural perspective (McGrath and MacMillan, 1992; McGrath et al., 1992; Davidsson, 1995; Mueller and Thomas, 2000; Busenitz et al., 2000; Hofstede et al., 2004; Uhlaner et al., 2002, Noorderhaven et al., 2004; Shane, 1992; 1993). 
${ }^{27}$ Life satisfaction may be more likely to be related to job satisfaction for men than for women, in particular since employment often absorbs more time in the lives of men.

${ }^{28}$ Based on the empirical evidence provided by Noorderhaven et al. (2004) we choose our hypothesis to be in line with the social legitimation perspective.

${ }^{29}$ The values for the informal sector variable range from 3.8 to 4.8 for the four countries and this corresponds with an estimated size of the informal sector of approximately 20 to 35 percent of the economy (see Table 3). Note that 'informal' is not the same as 'illegal'.

${ }^{30}$ Note that the correlation between female share in entrepreneurial activity and size of the informal sector is positive and significant $(r=0.54, p<0.01)$. See Table 4 . Remarkably, Chile scores low on both variables, contributing to the positive relationship. Chile combines a score of only 1.7 on the informal sector index, with a low share of women in total entrepreneurship (30.3 percent). See Table 2. Apparently, informal entrepreneurship by women occurs less often in Chile as compared to other Latin American countries such as Argentina and Brazil.

${ }^{31}$ Note that the negative Hypothesis 5 relates to official or formal entrepreneurial activity.

32 The questions asked in the GEM Adult Population Survey do not necessarily exclude owner-managers of unofficial businesses. In particular, respondents who indicate that they "sell any goods or services to others" are included in the TEA index. The fact that the Adult Population Survey is a survey among randomly selected adults does also not give reason to assume that unofficial entrepreneurs are excluded from the TEA count.

${ }^{33}$ Per capita income and squared per capita income are counted separately.

${ }^{34}$ During the general-to-specific modeling procedure we applied two-tailed tests because removal of variables with high $t$-values but with a sign opposite to the predicted sign would give biased results. However, note that the effects of the selected variables in Table 6 are interpreted in terms of one-tailed tests.

${ }^{35}$ Note that not all of these variables are marked as significant in Table 5 because we did one-sided tests. However, a high $t$-value does seem to indicate that there is an effect, even if the effect is not consistent with the sign of the effect in the corresponding hypothesis.

${ }^{36}$ Wennekers et al. (2005) provide empirical support for a U-shaped relation between the 'innovative capacity index' (see Global Competitiveness Report) and the nascent entrepreneurship rate of the Global Entrepreneurship Monitor. The downward part of the curve reflects the Schumpeter II regime (creative accumulation), where the innovative advantage lies with large, established firms. The upward part of the curve reflects the Schumpeter I regime (creative destruction), where the technological regime is more favorable to innovative entry.

${ }^{37}$ Although life satisfaction has a significant impact on female entrepreneurial activity in Table 6. Note however that the sign is opposite to what was predicted in Hypothesis 12.

${ }^{38}$ Again here we select variables based on two-tailed tests. Selection based on one-tailed tests would create a bias if we were to exclude variables with high $t$-values but with an unpredicted sign. See also note 34 .

${ }^{39}$ Reversed causality (i.e., a positive effect of self-employment on satisfaction of women) is not an issue here as entrepreneurial activity refers to only a part of the population (20 percent at most, see Table 1), while the life satisfaction variable is an average country score (see Table 3) referring to the whole population. Even if (female) entrepreneurs report to be more satisfied with their life as compared to (female) wage earners, it is unlikely that this has a large impact on the life satisfaction variable as this refers to the whole population of a country.

${ }^{40}$ For women this was partly due to multicollinearity (see Table 6). Also note that the absolute effect of life satisfaction is larger for women (see Table 5). Thus, given the smaller number of female entrepreneurs the significant effect on the female share of entrepreneurs is not surprising.

${ }^{41}$ Indeed, comparing Tables 5, 6, 7 and 8, we see that, by and large, the ordering of variables based on the size of the effects is quite similar to the ordering based on the significance (t-values) of the effects. We feel that this increases the credibility of our estimation results.

${ }^{42}$ Female and male unemployment rates for 2001 and data on the employment levels of women and men in the service sector for 2000 are obtained from the ILO LABORSTA database (http://laborsta.ilo.org). No genderspecific unemployment data are available for India. Instead, we make use of the general unemployment rate in India to enable comparisons between the analyses using either general or gender-specific variables. For the same reason, we use the general service employment rate for South Africa. (Fe)male employment in the service sector is scaled on total (fe)male employment. For employment definitions and measurement per country we refer to Verheul (2005), Chapter 2. Gender-specific data for importance of family and life satisfaction are obtained from the World and European Values Surveys. Average country scores for women and men are used.

${ }^{43}$ Indeed, most of the research in the area of female entrepreneurship focuses upon Anglo-Saxon countries (Verheul, 2005).

${ }^{44}$ The possibility of including more countries is largely dependent on the number of countries participating in GEM. In 2003 and 2004 the number of participating countries in GEM was lower than that in 2002. To safeguard a sufficient number of observations in our analyses in this paper we used data of 2002. Also note that pooling of data of different years is no option as the effect of the business cycle would distort results (Reynolds et al., 2002). 
${ }^{45}$ Note that the variables 'informal sector' and 'former communist country' already account for some of these possible differences between different parts of the world. 


\section{Publications in the ERIM Report Series Research* in Management}

\section{ERIM Research Program: "Organizing for Performance"}

2005

Continuous versus Step-Level Public Good Games

Susanne Abele and Garold Stasser

ERS-2005-015-ORG

$\underline{\text { http://hdl.handle.net/1765/1937 }}$

Collective Consuming: Consumers as Subcontractors on Electronic Markets

Wilfred Dolfsma

ERS-2005-020-ORG

$\underline{\text { http://hdl.handle.net/1765/1932 }}$

Appropriability in Services

Wilfred Dolfsma

ERS-2005-021-ORG

http://hdl.handle.net/1765/1926

Is China a Leviathan?

Ze Zhu and Barbara Krug

ERS-2005-031-ORG

http://hdl.handle.net/1765/6551

Information Sharing and Cognitive Centrality

Susanne Abele, Garold Stasser and Sandra I. Vaughan-Parsons

ERS-2005-037-ORG

http://hdl.handle.net/1765/6664

Virtual Enterprises, Mobile Markets and Volatile Customers

Ferdinand Jaspers, Willem Hulsink and Jules Theeuwes

ERS-2005-039-ORG

http://hdl.handle.net/1765/6728

No Black Box and No Black Hole: from Social Capital to Gift Exchange

Rene van der Eijk, Wilfred Dolfsma and Albert Jolink

ERS-2005-040-ORG

http://hdl.handle.net/1765/6665

Boards in Agricultural Cooperatives: Competence, Authority, and Incentives

G.W.J. Hendrikse

ERS-2005-042-ORG

$\underline{\text { http://hdl.handle.net/1765/6883 }}$

Finding Team Mates who are not prone to Sucker and Free-Rider effects: The Protestant Work Ethic as a Moderator of Motivation Losses in Group Performance

Susanne Abele and Michael Diehl

ERS-2005-053-ORG

$\underline{\text { http://hdl.handle.net/1765/6990 }}$

Organization and Strategy of Farmer Specialized Cooperatives in China

Yamei Hu, Zuhui Huang, George Hendrikse and Xuchu Xu

ERS-2005-059-ORG

$\underline{\text { http://hdl.handle.net/1765/6995 }}$ 
The Influence of Employee Communication on Strategic Business Alignment

Cees B. M. van Riel, Guido Berens and Majorie Dijkstra

ERS-2005-060-ORG

http://hdl.handle.net/1765/6996

The Tsunami's CSR Effect: MNEs and Philanthropic Responses to the Disaster

Gail Whiteman, Alan Muller, Judith van der Voort, Jeroen van Wijk, Lucas Meijs and Cynthia Piqué

ERS-2005-062-ORG

http://hdl.handle.net/1765/6994

Bridging Structure and Agency: Processes of Institutional Change

Wilfred Dolfsma and Rudi Verburg

ERS-2005-064-ORG

http://hdl.handle.net/1765/7014

Accounting as Applied Ethics: Teaching a Discipline

Wilfred Dolfsma

ERS-2005-065-ORG

http://hdl.handle.net/1765/7021

Institutions, Institutional Change, Language, and Searle

John Finch, Robert McMaster and Wilfred Dolfsma

ERS-2005-067-ORG

http://hdl.handle.net/1765/7109

Reflexivity in Teams: A Measure and Correlates

Michaéla C. Schippers, Deanne N. den Hartog and Paul L. Koopman

ERS-2005-069-ORG

http://hdl.handle.net/1765/7117

The Role of Team Leadership in Enhancing Team Reflexivity and Team Performance

Michaéla C. Schippers, Deanne N. den Hartog, Paul L. Koopman and Daan van Knippenberg

ERS-2005-070-ORG

The Psychological Benefits of Superstitious Rituals in Top Sport

Michaéla C. Schippers and Paul A.M. Van Lange

ERS-2005-071-ORG

http://hdl.handle.net/1765/7118

The Impact of New Firm Formation on Regional Development in the Netherlands

André van Stel and Kashifa Suddle

ERS-2005-075-ORG

http://hdl.handle.net/1765/7131

Allocation and Productivity of Time in New Ventures of Female and Male Entrepreneurs

Ingrid Verheul, Martin Carree and Roy Thurik

ERS-2005-082-ORG

Internationalization and Performance: The Moderating Role of Strategic Fit

Fabienne Fortanier, Alan Muller and Rob van Tulder

ERS-2005-083-ORG

Exploring Patterns of Upstream Internationalization: The Role of Home-region 'Stickiness'

Alan Muller and Rob van Tulder

ERS-2005-084ORG

The Search for Synergy between Institutions and Multinationals: Institutional Uncertainty and Patterns of Internationalization Alan Muller and Rob van Tulder ERS-2005-086-ORG 
Is China a Leviathan? (revised)

Ze Zhu and Barbara Krug

ERS-2005-087-ORG

China's Emerging Tax Regime: Local Tax Farming and Central Tax Bureaucracy

Ze Zhu and Barbara Krug

ERS-2005-087-ORG

Explaining Female and Male Entrepreneurship at the Country Level

Ingrid Verheul, André van Stel and Roy Thurik

ERS-2005-089-ORG

* A complete overview of the ERIM Report Series Research in Management: https://ep.eur.nl/handle/1765/1

ERIM Research Programs:

LIS Business Processes, Logistics and Information Systems

ORG Organizing for Performance

MKT Marketing

F\&A Finance and Accounting

STR Strategy and Entrepreneurship 